\title{
Concordancias, relaciones, contenido y alcance del derecho a un recurso judicial efectivo en la jurisprudencia de la corte interamericana de derechos humanos, con especial referencia al derecho de acceso a la justicia
}

\author{
Milton C. Feuillade \\ Argentina \\ miltonfeuillade@hotmail.com \\ Doctor en Derecho por la \\ Universidad de Barcelona. \\ Investigador del CONICT \\ (Consejo Nacional de Investigaciones \\ Científicas y Técnicas de la \\ República Argentina). \\ Recebido em 31/08/2010 \\ Aprovado em 24/03/2010
}

\section{Resumen}

El derecho a un recurso judicial efectivo emanando también el derecho enunciado de posee el rango de principio y de costumbre los artículos 1.1, 2 y 8 de la Convención. Su ámbito de aplicación es el de garantizar que del Derecho Internacional. Su desarrollo en la jurisprudencia interamericana ha sido progresivo y sin contradicciones. El derecho a un recurso judicial efectivo posee una estrecha relación con las obligaciones generales consagradas en la Convención y con el art. 8.1 de ella, constituyéndose como un derecho autónomo, no absoluto, cuyo límite es la no denegación de justicia y en ningún caso las limitaciones pueden llevar a contravenir obligaciones internacionales. En su relación con el derecho de acceso la justicia, el artículo 25 se constituye como uno de sus cimientos, pero no es el único, los Estados, como deber positivo, otorguen y desarrollen recursos efectivos para la salvaguarda de los derechos, centrados por una parte en el amparo de los derechos fundamentales, pero que a su vez no se circunscribe solamente a ello, sino que abarca todo derecho fundamental reconocido en la Convención, la Constitución o la ley.

\section{Palabras clave}

Recurso JudicialEfectivo. Derecho de Acceso a la Justicia. Relaciones. Jurisprudencia Interamericana. 


\title{
Matches, relationships, content and scope of right to an effective judicial remedy in the Inter-American Court of Human Rights decisions, with special reference to the right to access to justice
}

\author{
Milton C. Feuillade
}

Abstract

The right to an effective judicial remedy bas the degree of principle and practice of International Law. Its development in inter-american decisions has been gradual and without contradictions. The right to an effective judicial remedy has a close relationship with the general obligations enshrined in the Convention and the 8.1 article of $i t$. Is constituted as an autonomos right, not absolute. The no denial of justice and International Law general obligations, is her regulation limit. Article 25 constitutes one of its foundations in relationship with the right to justice access, but not alone, also comes the right wording of articles 1.1, 2 and 8 of Convention. Its scope is to ensure that States, as a positive duty, extend and develop effective procedures for safeguarding rights, focusing on the one hand in the protection of fundamental rights, but that in turn is not confined only to Thus, also covers every right recognized in the Convention, the Constitution or domestics laws.

Key Words

Effective Judicial Remedy. Right to Justice Access. Relationships. Interamerican Decisions. 


\section{Sumario}

1 Introducción

1.1 Principio general del Derecho Internacional

1.2 Pilar de la Convención Americana y del Estado de Derecho

2 Concordancia con otros derechos y deberes establecidos en la Convención

2.1 Obligaciones generales

2.1.1 Respeto de los derechos y libertades consagrados

2.1.2 Obligación de adaptar el derecho interno

2.2 Relación con el Derecho de Acceso a la Justicia

2.3 Relación con las garantías del debido proceso

2.4 Relación con el deber de investigar

2.4.1 Como medio para evitar la impunidad

3 Contenido del derecho a un recurso judicial efectivo

4 Alcance del derecho a un recurso judicial efectivo

4.1 Como derecho no absoluto

4.2 Como respuesta en un plazo razonable

4.3 Deber de cumplimiento de las sentencias

4.4 Necesidad de motivación de las decisiones

4.5Situaciones de denegación de justicia

4.5.1 Acción directa de agentes estatales

4.5.2 Falta de respuesta estatal como indicio grave

4.5.3 Alegación de disposiciones de amnistía o prescripción

4.5.4 Regla del previo agotamiento de recursos internos

5 Conclusiones

6 Bibliografía

6.1 Autores

6.2Normas

6.3Opiniones consultivas 


\section{Introducción}

En estas páginas, principalmente desde la jurisprudencia de la Corte IDH, se pretenden establecer las relaciones, concordancias, contenido y alcance del derecho a un recurso judicial efectivo ${ }^{1}$, con las obligaciones generales de la CADH y otras normas del instrumento con la que se lo liga, formulando a su vez la vinculación de este derecho con el derecho de acceso a la justicia en el Sistema Interamericano.

Para un posterior estudio dejaremos los demás aspectos de este amplio derecho, en particular lo concerniente a los requisitos exigidos para el cumplimiento del derecho de acceso a un recurso judicial efectivo y la mención que a alguno de ellos se haga a lo largo de la exposición será solamente en relación al tema principal propuesto.

Nos centraremos en la jurisprudencia de la Corte IDH en la materia, aclarando que no nos es ajeno que, con mayor o menor intensidad, existen diferentes instrumentos que regulan el tema y que sobre la Convención Americana sobre Derechos Humanos también se ha producido abundante jurisprudencia derivada de la CIDH, más no nos abocaremos a ello por no estar dentro de los objetivos de la investigación en esta primera etapa de trabajo la labor comparada normativa y jurisprudencial ${ }^{2}$.

En el mismo sentido, las referencias doctrinarias son mínimas. Ello no es por descuido, sino por considerar que de este modo se responde mejor a los fines del trabajo centrado en un análisis jurisprudencial, que a nuestro criterio no se vería expresado de forma pura si se volcasen junto a ellos las interpretaciones que los estudiosos han hecho de lo dicho por el alto tribunal a través de sus fallos y opiniones.

1 Recordamos que establece el artículo 25: «1. Toda persona tiene derecho a un recurso sencillo y rápido o a cualquier otro recurso efectivo ante los jueces o tribunales competentes, que la ampare contra actos que violen sus derechos fundamentales reconocidos por la Constitución, la ley o la presente Convención, aun cuando tal violación sea cometida por personas que actúen en ejercicio de sus funciones oficiales. 2. Los Estados Partes se comprometen: a) a garantizar que la autoridad competente prevista por el sistema legal del Estado decidirá sobre los derechos de toda persona que interponga tal recurso; b) a desarrollar las posibilidades de recurso judicial, y c) a garantizar el cumplimiento, por las autoridades competentes, de toda decisión en que se haya estimado procedente el recurso».

2 Puede consultarse: O'Donell, Daniel. Derecho internacional de los Derechos Humanos - Normativa, jurisprudencia y doctrina de los sistemas Universal e Interamericano, Bogotá, Alejandro Valencia Villa, 2004. En particular sobre la jurisprudencia de la CIDH en relación al recurso judicial efectivo, págs. 463 a 517. Si se desea examinar la jurisprudencia de la Comisión de Naciones Unidas para los Derechos Humanos, puede verse: Alto Comisionado de las Naciones Unidas para los Derechos Humanos - Oficina de Colombia. Interpretación de las normas internacionales sobre derechos humanos, Bogotá, 2002. También: Alto Comisionado de las Naciones Unidas para los Derechos Humanos. Recomendaciones de órganos internacionales de derechos humanos al estado colombiano, en especial el capítulo destinado al recurso judicial efectivo. 
Sin embargo, como referencia inicial, diremos que sobre el alcance y normas que comprenden en el Sistema Interamericano de Protección de los Derechos Humanos, el: «derecho de acceso a la justicia», «derecho a un recurso judicial efectivo» y la relación de estos con el «derecho a la justicia»" existen diferentes debates en la doctrina y en el seno de la Corte IDH.

Si se analizan los fallos del alto tribunal, desde su inicio, podrá observarse que es en el caso Castillo Petruzzi y otros Vs. Perú ${ }^{4}$ donde se utiliza por primera vez la expresión «derecho de acceso a la justicia», lo cual podría hacer presuponer que anteriormente el derecho a un recurso judicial efectivo se utilizaba como sinónimo de derecho de acceso a la justicia ${ }^{5}$, aunque no creemos que haya sido entendido de este modo por la Corte IDH.

Cierto sector de la doctrina ${ }^{6}$ ha planteado y criticado que la Corte IDH sobre este punto no haya dado una definición unívoca. Nosotros nos planteamos si tiene el deber de hacerlo y creemos que no en sus sentencias. En este sentido no hemos vislumbrado en esta cuestión falta de fundamentación en los fallos por parte del alto tribunal, que se ha centrado siempre y de forma correcta en la resolución de la litis planteada, de este modo, es dable resaltar que en sus primeros fallos cuando se refería a los artículos 8 y 25 del Pacto lo hacía en relación y contexto a la violación de otros derechos infringidos en la Convención y será recién en el caso Cantos Vs. Argentina ${ }^{7}$ donde tendrá que evaluar el tema como cuestión autónoma.

Quien ha llevado el estandarte de la concepción del Derecho de Acceso a la Justicia como derecho autónomo ha sido el juez Antonio Cançado Trindade, a partir de su voto concurrente en el caso «Cinco Pensionistas» Vs. Perú

3 Sobre el derecho a la justicia, consideramos que la exigencia de la justicia material demarca el derecho a la justicia, donde aparece concatenada la posibilidad de un recurso judicial efectivo. En Corte IDH. Caso Myrna Mack Chang Vs. Guatemala. Fondo, Reparaciones y Costas. Sentencia de 25 de noviembre de 2003. Serie C N. ${ }^{\circ}$ 101, en su voto concurrente, el entonces presidente de la Corte, juez Sergio García Ramírez, en el párr. 5 se ocupa particularmente del tema y sobre esto más adelante expondremos en detalle. Todos los casos citados se refieren a expedientes de la Corte Interamericana de Derechos Humanos, Corte IDH.

4 Caso Castillo Petruzzi y otros Vs. Perú. Fondo, Reparaciones y Costas. Sentencia de 30 de mayo de 1999. Serie C N. ${ }^{\text {5 }}$ 2, párr. 128.

5 Acosta Alvarado, Paola Andrea. El derecho de acceso a la justicia en la jurisprudencia interamericana, Bogotá, Universidad Externado de Colombia, 2007, 139 págs., pág. 16.

6 Ibíd., pág. 16.

7 Caso Cantos Vs. Argentina. Fondo, Reparaciones y Costas. Sentencia de 28 de noviembre de 2002. Serie C N. 97.

8 Caso «Cinco Pensionistas»Vs. Perú. Fondo, Reparaciones y Costas. Sentencia de 28 de febrero de 2003. Serie C N. ${ }^{\circ}$ 98, donde se dice en el párr. 2 del mencionado voto: «De la presente Sentencia de la Corte se desprende el amplio alcance del derecho de acceso a la justicia, en los planos tanto nacional como internacional. Tal derecho no se reduce al acceso formal, stricto sensu, a la instancia judicial; el derecho de acceso a la justicia, que se encuentra implícito en diversas disposiciones de la Convención Americana (y de otros tratados de derechos humanos) y que permea el derecho interno de los Estados Partes, significa, lato sensu, el derecho a obtener justicia. Dotado de contenido jurídico propio, configúrase como un derecho autónomo 
Importante también es la consideración de la postura de la jueza Cecilia Medina Quiroga, que deriva el derecho de acceso a la justicia de la obligación general establecida en el artículo 1.1 de la Convención y no del artículo 25, que a su criterio se circunscribe a la protección por medio del recurso de amparo de los derechos fundamentales consagrados?

A continuación intentaremos realizar una dilucidación y aporte a lo planteado, desde los fallos de la Corte IDH.

\subsection{Principio general del Derecho Internacional}

Hemos considerado necesario detenernos en este punto, porque como se verá, el derecho a un recurso judicial efectivo, posee para la Corte IDH el rango de principio general del derecho internacional. ${ }^{10}$

La Corte IDH ha utilizado esta fuente ${ }^{11}$ en diversas ocasiones y en específico a su alcance dentro del recurso judicial efectivo y en este aspecto, la combinación o interrelación en la Convención, del artículo 25 referido a protección judicial con el 46

a la prestación jurisdiccional, o sea, a la propia realización de la justicia». El planteo doctrinal actual y propuesta de que sea asumido por la Corte IDH, por parte del juez Cançado Trindade, es que el derecho de acceso a la justicia sea considerado como norma de ius cogens, a partir del tratamiento del contenido del ius cogens en condición jurídica y derechos de los migrantes indocumentados.

9 Esto se verá expresado en: caso 19 Comerciantes Vs. Colombia. Fondo, Reparaciones y Costas. Sentencia de 5 de julio de 2004. Serie C N. ${ }^{\circ}$ 109, voto parcialmente disidente de la jueza Medina Quiroga, párr. 1. Caso de los Hermanos Gómez Paquiyauri Vs. Perú. Fondo, Reparaciones y Costas. Sentencia de 8 de julio de 2004. Serie C N. ${ }^{\circ} 110$, voto parcialmente disidente de la jueza Medina Quiroga, párr. 1. Caso Gómez Palomino Vs. Perú. Fondo, Reparaciones y Costas. Sentencia de 22 de noviembre de 2005. Serie C N. ${ }^{\circ}$ 136, voto concurrente de la jueza Medina Quiroga, párrs. 4-5. Se puede ver también su opinión doctrinal en: Medina Quiroga, Cecilia. La Convención Americana: teoría y jurisprudencia. Vida, integridad personal, libertad personal, debido proceso y recurso judicial, San José, Universidad de Chile, 2005.

10 La referencia que el alto tribunal realiza de esta fuente goza de una muy antigua raíz y ha sido utilizada por la jurisprudencia a nivel general a lo largo de los siglos. Por ello la Comisión Redactora del Estatuto de la Corte Permanente de Justicia Internacional los estableció en el artículo 38 inc. 3 del mencionado cuerpo y permaneció en el actual Estatuto de la Corte Internacional de Justicia, incorporada como órgano principal de Naciones Unidas y habla de los: «Principios generales del derecho reconocidos por las naciones civilizadas». De la lectura del texto nos surge la pregunta sobre el alcance de la expresión «naciones civilizadas», que encuentra su origen en la concepción de que la comunidad internacional estaba formada por las naciones cristianas de Europa. Hoy día con la descolonización y el ingreso de la generalidad de los Estados en ONU, que aceptan los principios que rigen el derecho de gentes, no puede hablarse de que existan naciones no civilizadas, es por ello que la Corte Interamericana habla solamente de los «Principios Generales del Derecho Internacional».

11 A lo largo del tiempo la doctrina ha mantenido distintas posiciones acerca de la real juridicidad de estos principios. Nosotros creemos que hoy en día no puede ponerse en duda su existencia 
sobre requisitos de admisibilidad ante la $\mathrm{CIDH}$, que en referencia al agotamiento de los recursos internos en su inc. 1 a) menciona expresamente a: «... los principios del Derecho Internacional Generalmente Reconocidos» y allí entonces su fundamento positivo en la Convención.

En particular el Tribunal Interamericano ha dicho que: «Esos principios no se refieren sólo a la existencia formal de tales recursos, sino también a que éstos sean adecuados y efectivos, como resulta de las excepciones contempladas en el artículo 46.2 ${ }^{12}$.

Las bases jurisprudenciales sobre los principios generales del Derecho coinciden con el texto y consisten en que: «... toda persona tiene derecho a un recurso sencillo y rápido o a cualquier otro recurso efectivo ante los jueces o tribunales competentes ${ }^{13}$. O sea que puede decirse, que para la Corte IDH el derecho de acceso a un recurso judicial efectivo para peticionar la tutela de un derecho posee el rango de principio del derecho internacional.

y calidad de derecho, por más que no se presenten siempre como una proposición normativa, sino a veces conceptual. Como referencia, muchos de los grandes principios del derecho internacional están plasmados en la Carta de las Naciones Unidas y han sido posteriormente explicitados en resoluciones de la Asamblea General, como la 2625, del 24 de octubre de 1970. Existen dos clases de principios generales del derecho, así, puede hablarse de principios generales del derecho interno y los principios generales del derecho internacional. Si bien los principios generales del derecho interno, son una generalización de las normas jurídicas internas, desde el despojo de los elementos particulares de la norma, cuando pasamos al plano internacional, deberá encontrarse una constante en ellos a partir de un número considerable de legislaciones internas. Estos elementos son los que se universalizan en el orden jurídico internacional. Si se desea profundizar sobre las posturas doctrinales a lo largo del tiempo y actuales puede verse: VIRALLY, Michel. El devenir del derecho internacional, trad. Tipie Isoard, Eliane Cazenave, México, Fondo de Cultura Económica, 1998, pág. 222. Sobre su concepto y elementos que lo configuran, así como su relación con las otras fuentes del derecho internacional, puede verse: BARBERIS, Julio A. Formación del derecho internacional, Buenos Aires, Ábaco de Rodolfo Depalma, 1994, págs. 241 y ss.

12 Caso Velásquez Rodríguez Vs. Honduras. Fondo. Sentencia del 29 de julio de 1988. Serie C N. ${ }^{\circ}$ 4, párr. 63. Caso Godínez Cruz Vs. Honduras. Fondo. Sentencia del 20 de enero de 1989. Serie C N. ${ }^{\circ}$ 5, párr. 66. Caso Fairén Garbi y Solís Corrales Vs. Honduras. Fondo. Sentencia del 15 de marzo de 1989. Serie C N. ${ }^{\circ}$ 6, párr. 87. Caso Caballero Delgado y Santana Vs. Colombia. Excepciones Preliminares. Sentencia del 21 de enero de1994. Serie C N. ${ }^{\circ}$ 17, párr. 63. Recordamos que las excepciones establecidas en el artículo 46.2 son: «Las disposiciones de los incisos 1.a. y 1.b. del presente artículo no se aplicarán cuando: a) no exista en la legislación interna del Estado de que se trata el debido proceso legal para la protección del derecho o derechos que se alega han sido violados; b) no se haya permitido al presunto lesionado en sus derechos el acceso a los recursos de la jurisdicción interna, o haya sido impedido de agotarlos, y c) haya retardo injustificado en la decisión sobre los mencionados recursos».

13 Caso Castillo Páez Vs. Perú. Fondo. Sentencia de 3 de noviembre de 1997. Serie C N. ${ }^{\circ}$ 34, párr. 82. Suárez Rosero, op. cit., párr. 65. Caso Blake Vs. Guatemala. Fondo. Sentencia de 24 de enero de 1998. Serie C N. ${ }^{\circ}$ 36, párr. 102. Caso de la «Panel Blanca» (Paniagua Morales y otros) Vs. Guatemala. Fondo. Sentencia de 8 de marzo de 1998. Serie C N. 37, párr. 164. Caso Loayza Tamayo Vs. Perú. Reparaciones y Costas. Sentencia de 27 de noviembre de 1998. Serie 


\subsection{Pilar de la Convención Americana y del Estado de Derecho}

La interpretación primaria que la Corte IDH realiza sobre la protección judicial consagrada en el artículo 25 parte de las propias palabras de sus magistrados y puede citarse así: «Esta disposición sobre el derecho a un recurso efectivo ante los jueces o tribunales nacionales competentes constituye uno de los pilares básicos, no sólo de la Convención Americana, sino del propio Estado de Derecho en una sociedad democrática en el sentido de la Convención» ${ }^{14}$.

Esta protección del primer párrafo del artículo 25 a un recurso sencillo, rápido y efectivo, ante los jueces o los tribunales competentes, como base que trasciende a la

C N. ${ }^{\circ}$ 42, párr. 169. Caso Castillo Páez Vs. Perú. Reparaciones y Costas. Sentencia de 27 de noviembre de 1998. Serie C N. ${ }^{\circ} 48$, párr. 63. Cesti Hurtado, op. cit., párr. 121. Caso de los «Niños de la Calle» (Villagrán Morales y otros) Vs. Guatemala. Fondo. Sentencia de 19 de noviembre de 1999. Serie C N. o 63, párr. 234. Caso Bámaca Velásquez Vs. Guatemala. Fondo. Sentencia de 25 de noviembre de 2000. Serie C N. ${ }^{\circ}$ 70, párr. 191. Caso del Tribunal Constitucional Vs. Perú. Fondo, Reparaciones y Costas. Sentencia de 31 de enero de 2001. Serie C N. ${ }^{\circ}$ 71, párr. 90. Caso Cesti Hurtado Vs. Perú. Reparaciones y Costas. Sentencia de 31 de mayo de 2001. Serie C N. ${ }^{7}$ 78, párr. 66. Caso de la Comunidad Mayagna (Sumo) Awas Tingni Vs. Nicaragua. Fondo, Reparaciones y Costas. Sentencia de 31 de agosto de 2001. Serie C N. ${ }^{\circ}$ 79, párr. 112. Caso Hilaire, Constantine y Benjamin y otros Vs. Trinidad y Tobago. Fondo, Reparaciones y Costas. Sentencia de 21 de junio de 2002. Serie C N. . 94, párr. 150. Cantos, op. cit., 52. Caso Juan Humberto Sánchez Vs. Honduras. Excepción Preliminar, Fondo, Reparaciones y Costas. Sentencia de 7 de junio de 2003. Serie C N. ${ }^{\circ}$ 99, párr. 121. Caso Maritza Urrutia Vs. Guatemala. Fondo, Reparaciones y Costas. Sentencia de 27 de noviembre de 2003. Serie C N. ${ }^{\circ} 103$, párr. 117. Caso López Álvarez Vs. Honduras. Fondo, Reparaciones y Costas. Sentencia de 1 de febrero de 2006. Serie C N. ${ }^{\circ}$ 141, párr. 138.

14 Caso Castillo Páez Vs. Perú. Fondo. Sentencia de 3 de noviembre de 1997. Serie C N. 34 , párr. 82. Suárez Rosero, op. cit., párr. 65. Caso Blake Vs. Guatemala. Fondo. Sentencia de 24 de enero de 1998. Serie C N. ${ }^{\circ}$ 36, párr. 102. Caso de la «Panel Blanca» (Paniagua Morales y otros) Vs. Guatemala. Fondo. Sentencia de 8 de marzo de 1998. Serie C N. ${ }^{\circ} 37$, párr. 164. Caso Loayza Tamayo Vs. Perú. Reparaciones y Costas. Sentencia de 27 de noviembre de 1998. Serie C N. ${ }^{\circ} 42$, párr. 169. Caso Castillo Páez Vs. Perú. Reparaciones y Costas. Sentencia de 27 de noviembre de 1998. Serie C N. ${ }^{\circ} 48$, párr. 63. Cesti Hurtado, op. cit., párr. 121. Caso de los «Niños de la Calle» (Villagrán Morales y otros) Vs. Guatemala. Fondo. Sentencia de 19 de noviembre de 1999. Serie C N. o 63, párr. 234. Caso Bámaca Velásquez Vs. Guatemala. Fondo. Sentencia de 25 de noviembre de 2000. Serie C N. ${ }^{\circ}$ 70, párr. 191. Caso del Tribunal Constitucional Vs. Perú. Fondo, Reparaciones y Costas. Sentencia de 31 de enero de 2001. Serie C N. ${ }^{\circ}$ 71, párr. 90. Caso Cesti Hurtado Vs. Perú. Reparaciones y Costas. Sentencia de 31 de mayo de 2001. Serie C N. ${ }^{7}$, párr. 66. Caso de la Comunidad Mayagna (Sumo) Awas Tingni Vs. Nicaragua. Fondo, Reparaciones y Costas. Sentencia de 31 de agosto de 2001. Serie C N. ${ }^{\circ}$ 79, párr. 112. Caso Hilaire, Constantine y Benjamin y otros Vs. Trinidad y Tobago. Fondo, Reparaciones y Costas. Sentencia de 21 de junio de 2002. Serie C N. ${ }^{0}$ 94, párr. 150. Cantos, op. cit., 52. Caso Juan Humberto Sánchez Vs. Honduras. Excepción Preliminar, Fondo, Reparaciones y Costas. Sentencia de 7 de junio de 2003. Serie C N. 99 , párr. 121. Caso Maritza Urrutia Vs. Guatemala. Fondo, Reparaciones y Costas. Sentencia de 27 de noviembre de 2003. Serie C N. ${ }^{\circ} 103$, párr. 117. Caso López Álvarez Vs. Honduras. Fondo, Reparaciones y Costas. Sentencia de 1 de febrero de 2006. Serie C N. ${ }^{\text {141, párr. } 138 .}$ 
Convención misma, debe amparar a la persona contra todo acto que viole: «... sus derechos fundamentales reconocidos por la Constitución, la ley o la Convención, inclusive cuando tal violación sea cometida por personas que actúen en ejercicio de sus funciones oficiales» ${ }^{15}$.

El fundamento de la trascendencia que en cuanto «pilan» se le otorga, consiste en que: «... contribuye decisivamente a asegurar el acceso a la justicia» ${ }^{16}$, al punto que se ha declarado que se encuentra íntimamente ligado con: «... la obligación general del artículo 1.1 de la Convención Americana, al atribuir funciones de protección al derecho interno de los Estados Partes» ${ }^{17}$.

\section{Concordancia con otros derechos y deberes establecidos en la Convención}

Desde los parámetros que expondremos se verá la integralidad de la norma y su funcionamiento para la defensa de los derechos fundamentales. El carácter del recurso judicial efectivo es sistémico e instrumental, concordante, interdependiente de otros derechos consagrados ${ }^{18}$ en la Convención y al mismo tiempo independiente, en cuanto derecho autónomo.

\subsection{Obligaciones generales}

El recurso judicial efectivo ha sido relacionado de manera conjunta con las obligaciones generales de los artículos 1.1 y 2 de la Convención, de este modo en el caso Barrios Altos Vs. Perú se determinó que: «La Corte estima necesario enfatizar que, a la luz de las obligaciones generales consagradas en los artículos 1.1 y 2 de la Convención Americana, los Estados Partes tienen el deber de tomar las

15 Blake, op. cit., párr. 101. Tribunal Constitucional, op. cit., párr. 89. Comunidad Mayagna (Sumo) Awas Tingni, op. cit., párr. 111.

16 Caso Blake Vs. Guatemala. Reparaciones y Costas. Sentencia de 22 de enero de 1999. Serie C N. ${ }^{\circ} 48$, párr. 63.

17 No solamente en los aspectos estrictamente procesales, de este modo en el caso Castañeda Gutman Vs. México. Excepciones Preliminares, Fondo, Reparaciones y Costas. Sentencia de 6 de agosto de 2008. Serie C N. ${ }^{\circ}$ 184, párr. 34., se dijo: «... la cuestión de los recursos internos se aproxima sensiblemente a la materia de fondo». Que si bien está realizada dentro del marco de una excepción preliminar, la consideramos ilustrativa e interesante.

18 Caso Barrios Altos Vs. Perú. Fondo. Sentencia de 14 de marzo de 2001. Serie C N. . 75, párr. 43. En el mismo sentido: caso Cantoral Benavides Vs. Perú. Reparaciones y Costas. Sentencia de 3 de diciembre de 2001. Serie C N. ${ }^{\circ}$ 88, párr. 73. Caso Bulacio Vs. Argentina. Fondo, Reparaciones y Costas. Sentencia de 18 de septiembre de 2003. Serie C N. ${ }^{\circ}$ 100, párr. 116. Caso Juan Humberto Sánchez Vs. Honduras. Interpretación de la Sentencia de Excepción Preliminar, Fondo y Reparaciones. Sentencia de 26 de noviembre de 2003. Serie C N. 102 , párr. 60. 
providencias de toda índole para que nadie sea sustraído de la protección judicial y del ejercicio del derecho a un recurso sencillo y eficaz, en los términos de los artículos 8 y 25 de la Convención» ${ }^{19}$.

Veremos entonces el tratamiento que se le ha dado al recurso judicial efectivo en correspondencia al deber general de respeto y pleno goce de los derechos y libertades establecidos para toda persona sujeta a la jurisdicción del Estado y la obligación de remover todo obstáculo legislativo o de otro carácter al efecto.

\subsubsection{Respeto de los derechos y libertades consagrados}

Como es sabido, el artículo 1.1 de la Convención ${ }^{20}$, establece la obligación y compromiso de todo Estado parte del sistema a respetar los derechos y libertades reconocidos en ella y a garantizar su libre y pleno ejercicio a toda persona que esté sujeta a su jurisdicción.

Es así que, cuando se analiza el recurso judicial efectivo, no debe verse el tema como un aspecto aislado o que refiere solamente a cuestiones procesales o rituales. La protección de los derechos humanos en el ámbito interamericano requiere una visión de conjunto dentro del Pacto de San José y a su vez en la totalidad general del marco convencional y legal del Estado.

Todo artículo en la Convención posee su correspondencia e integración con las otras normas, donde lo procesal se interrelaciona e interactúa con el derecho de fondo, poseyendo el artículo 25 en su autonomía un alcance que trasciende el mero trámite, sin perder su naturaleza.

Es así que la Corte IDH ha concordado el recurso judicial efectivo, con las obligaciones generales de la Convención. De este modo se ha dicho que: «El artículo 25 se encuentra íntimamente ligado con la obligación general del artículo 1.1 de la Convención Americana, al atribuir funciones de protección al derecho interno de los Estados Partes» ${ }^{21}$.

19 Caso Barrios Altos Vs. Perú. Fondo. Sentencia de 14 de marzo de 2001. Serie C N. o 75, párr. 43. En el mismo sentido: caso Cantoral Benavides Vs. Perú. Reparaciones y Costas. Sentencia de 3 de diciembre de 2001. Serie C N. 88, párr. 73. Caso Bulacio Vs. Argentina. Fondo, Reparaciones y Costas. Sentencia de 18 de septiembre de 2003. Serie C N. ${ }^{\circ} 100$, párr. 116. Caso Juan Humberto Sánchez Vs. Honduras. Interpretación de la Sentencia de Excepción Preliminar, Fondo y Reparaciones. Sentencia de 26 de noviembre de 2003. Serie C N. ${ }^{\circ} 102$, párr. 60.

20 Recordamos que dice el artículo 1.1 de la Convención: «Los Estados Partes en esta Convención se comprometen a respetar los derechos y libertades reconocidos en ella y a garantizar su libre y pleno ejercicio a toda persona que esté sujeta a su jurisdicción, sin discriminación alguna por motivos de raza, color, sexo, idioma, religión, opiniones políticas o de cualquier otra índole, origen nacional o social, posición económica, nacimiento o cualquier otra condición social».

21 Castillo Páez, op. cit., párr. 83. Suárez Rosero, op. cit., párr. 65. Blake, op. cit., párr. 102. Panel Blanca, op. cit., párr. 164. Loayza Tamayo, op. cit., párr. 169. Castillo Petruzzi, op. cit., párr. 
Resultado de esto es la responsabilidad del Estado de diseñar y consagrar normativamente recursos eficaces, así como la de asegurar la debida aplicación de dichos recursos por parte de sus autoridades judiciales ${ }^{22}$.

La ligazón de ambas normas, en cuanto la conexión del aspecto procesal del recurso judicial efectivo y la obligación general de derecho de acceso a la justicia, se deriva del deber positivo del Estado de garantizar la toma de medidas necesarias para remover todo obstáculo para que el individuo posea pleno goce de los derechos que la Convención reconoce: «Por consiguiente, la tolerancia del Estado a circunstancias o condiciones que impidan a los individuos acceder a los recursos internos adecuados para proteger sus derechos, constituye una violación al artículo 1.1 de la Convención» $»^{23}$. Y el Estado: «... debe adoptar todas las medidas necesarias, de carácter judicial y diplomático, para juzgar y sancionar a todos los responsables de las violaciones cometidas» ${ }^{24}$.

La especificación de las características de los recursos para que se cumpla con la obligación general del artículo 1.1, es que dichos procedimientos: «... sean accesibles y simples y que los órganos a su cargo cuenten con las condiciones técnicas y materiales necesarias para dar oportuna respuesta a las solicitudes que se les hagan en el marco de dichos procedimientos» ${ }^{25}$.

En otras oportunidades se ha puntualizado que la excesiva demora en la repuesta a un recurso de amparo, que era idóneo para el caso, viola el artículo 25.1, en combinación con el 1.1, lo cual demarca que un aspecto como el plazo razonable, puede infringir no sólo el Recurso Judicial Efectivo, sino las obligaciones generales de la Convención ${ }^{26}$.

184. Cesti Hurtado, op. cit., párr. 121. Niños de la Calle, op. cit., párr. 237. Cantoral Benavides, op. cit., párr. 163. Durand y Ugarte, op. cit., párr. 121. Caso Baena Ricardo y otros Vs. Panamá. Fondo, Reparaciones y Costas. Sentencia de 2 de febrero de 2001. Serie C N. ${ }^{\circ}$ 72, párr. 181. Ivcher Bronstein, op. cit., párrs. 168-170. Cesti Hurtado, op. cit., párr. 66. Hilaire Constantine, op. cit., párr. 151.

22 Comunidad Mayagna (Sumo) Awas Tingni, op. cit., párr. 135. Caso Comunidad Indígena Yakye Axa Vs. Paraguay. Fondo, Reparaciones y Costas. Sentencia 17 de junio de 2005. Serie C N. ${ }^{\circ}$ 125, párr. 99.

23 Bámaca Velásquez, op. cit., párr. 168. Ivcher Bronstein, op. cit., párrs. 169-170.

24 Caso del Penal Miguel Castro Castro Vs. Perú. Fondo, Reparaciones y Costas. Sentencia de 25 de noviembre de 2006. Serie C N. ${ }^{\circ} 160$, párr. 407. En particular la referencia del caso a las medidas de carácter diplomático hacen al pedido de extradición del ex presidente de la República del Perú Alberto Fujimori, para que comparezca al proceso en su contra, ver párr. 370 de la sentencia, entre otros.

25 Comunidad Indígena Sawhoyamaxa, op. cit., párr. 109.

26 Caso Apitz Barbera y otros («Corte Primera de lo Contencioso Administrativo») Vs. Venezuela. Excepción Preliminar, Fondo, Reparaciones y Costas. Sentencia de 5 de agosto de 2008. Serie C N. ${ }^{\text {1 }} 182$, párrs. 149-151 y 156. Sobre la ineficacia del recurso de amparo por falta de resolución en plazo razonable ver también: Tribunal Constitucional, op. cit., párrs. 91, 93 y 96. Comunidad 


\subsubsection{Obligación de adaptar el derecho interno}

El artículo 2 de la Convención ${ }^{27}$ establece la obligación por parte de los Estados de adecuación del derecho interno, para que sea efectivo el pleno goce de los derechos consagrados en el Pacto por sus habitantes ${ }^{28}$.

Así, ha dicho la Corte IDH en su relación con el artículo 25 que: «Esta obligación del Estado Parte implica que las medidas de derecho interno han de ser efectivas. Esto significa que el Estado ha de adoptar todas las medidas para que lo establecido en la Convención sea realmente cumplido en el orden jurídico interno. Y esas medidas son efectivas cuando la comunidad, en general, adapta su conducta a la normativa de la Convención y, en el caso de que así no sea, cuando se aplican efectivamente las sanciones previstas en ella $\rangle^{29}$. Las medidas abarcan lo judicial, legislativo y administrativo y en general toda medida necesaria, que a su vez debe ser tomada en un plazo razonable ${ }^{30}$.

Cuando la legislación es incompatible con la Convención, el Estado debe proceder a su rectificación y adecuación. Las consecuencias que esas leyes hubieren tenido en la práctica deben ser reparadas, por ejemplo, quitando al individuo de los registros de antecedentes penales ${ }^{31}$, impidiendo la aplicación de legislaciones sobre prescripción ${ }^{32}$ o la alegación de leyes de autoamnistía ${ }^{33}$.

Mayagna (Sumo) Awas Tingni, op. cit., párr. 134. Caso Acosta Calderón Vs. Ecuador. Fondo, Reparaciones y Costas. Sentencia de 24 de junio de 2005. Serie C N. ${ }^{\circ} 129$, párr. 97.

27 Dice textualmente: «Si el ejercicio de los derechos y libertades mencionados en el artículo 1 no estuviere ya garantizado por disposiciones legislativas o de otro carácter, los Estados Partes se comprometen a adoptar, con arreglo a sus procedimientos constitucionales y a las disposiciones de esta Convención, las medidas legislativas o de otro carácter que fueren necesarias para hacer efectivos tales derechos y libertades».

28 Hilaire Constantine, op. cit., párr. 152.

29 Cesti Hurtado, op. cit., párr. 167. Comunidad Indígena Sawhoyamaxa, op. cit., párrs. 110-111 y 235. Castañeda Gutman, op. cit., párr. 133. Destacamos: «En el presente caso la inexistencia de un recurso efectivo constituyó una violación de la Convención por el Estado Parte, y un incumplimiento de su deber de adoptar disposiciones de derecho interno para hacer efectivos los derechos establecidos en la Convención, en los términos del artículo 25 de la Convención Americana de Derechos Humanos, en relación con los artículos 1.1 y 2 de dicho tratado».

30 Comunidad Mayagna (Sumo) Awas Tingni, op. cit., párrs. 136-138 y 163-164. Comunidad Indígena Yakye Axa, op. cit., párrs. 100-102. Caso de las Niñas Yean y Bosico Vs. República Dominicana. Excepciones Preliminares, Fondo, Reparaciones y Costas. Sentencia de 8 de septiembre de 2005. Serie C N. ${ }^{\circ}$ 130, párr. 239.

31 Cantoral Benavides, op. cit., párrs. 74-78.

32 Hermanos Gómez Paquiyauri, op. cit., párrs. 151-152.

33 Barrios Altos, op. cit., párr. 44. Caso Barrios Altos Vs. Perú. Interpretación de la Sentencia de Fondo. Sentencia de 3 de septiembre de 2001. Serie C N. ${ }^{\circ}$ 83, párr. 15. Caso Almonacid Arellano y otros Vs. Chile. Excepciones Preliminares, Fondo, Reparaciones y Costas. Sentencia de 26 de septiembre de 2006. Serie C N. ${ }^{\circ}$ 154, párrs. 126-128. También, sobre la inadmisibilidad de las leyes de amnistía: Bulacio, op. cit., párr. 41. También: caso Trujillo Oroza Vs. Bolivia. 
Esta adecuación ha conllevado incluso a que se ordenen reformas constitucionales por parte del Estado, concibiendo a la Carta Magna, como derecho interno que no puede contrariar el Pacto ${ }^{34}$.

La referencia a «toda medida», es porque más allá de las normas quedan comprendidas las prácticas o costumbres que no se condigan con derechos reconocidos ${ }^{35}$.

Este ajuste debe ser visto, no sólo en las lagunas o las leyes preexistentes a la adhesión al Pacto por parte del Estado, sino que hace a la emisión de leyes posteriores, con o sin efecto retroactivo ${ }^{36}$.

La Corte IDH a este principio le otorga el rango de costumbre del derecho internacional, más allá de las consagraciones convencionales ${ }^{37}$. De este modo ha dicho: «Asimismo, en el derecho de gentes, una norma consuetudinaria prescribe que

Reparaciones y Costas. Sentencia de 27 de febrero de 2002. Serie C N. ${ }^{\circ}$ 92, párr. 10. Myrna Mack Chang, op. cit., párr. 276. Caso Molina Theissen Vs. Guatemala. Reparaciones y Costas. Sentencia de 3 de julio de 2004. Serie C N. ${ }^{\circ}$ 108, párr. 83. 19 Comerciantes, op. cit., párr. 262. Caso Tibi Vs. Ecuador. Excepciones Preliminares, Fondo, Reparaciones y Costas. Sentencia de 7 de septiembre de 2004. Serie C N. ${ }^{\circ}$ 114, párr. 259. Caso Masacre Plan de Sánchez Vs. Guatemala. Reparaciones y Costas. Sentencia de 19 de noviembre 2004. Serie C N. ${ }^{\circ} 116$, párr. 99. Caso Carpio Nicolle y otros Vs. Guatemala. Fondo, Reparaciones y Costas. Sentencia de 22 de noviembre 2004. Serie C N. ${ }^{\circ}$ 117, párr. 130. Hermanas Serrano Cruz, op. cit., párr. 172. Caso Huilca Tecse Vs. Perú. Fondo, Reparaciones y Costas. Sentencia de 03 de marzo de 2005. Serie C N. ${ }^{\circ} 121$, párr. 108. Caso Gutiérrez Soler Vs. Colombia. Fondo, Reparaciones y Costas. Sentencia de 12 de septiembre de 2005. Serie C N. 132 , párr. 97. Gómez Palomino, op. cit., párr. 140. Caso Blanco Romero y otros Vs. Venezuela. Fondo, Reparaciones y Costas. Sentencia de 28 de noviembre de 2005. Serie C N. 138, párr. 98. Baldeón García, op. cit., párr. 201. Caso de las Masacres de Ituango Vs. Colombia. Excepción Preliminar, Fondo, Reparaciones y Costas. Sentencia de 1 de julio de 2006 Serie C N. ${ }^{\circ}$ 148, párr. 402. Caso Montero Aranguren y otros (Retén de Catia) Vs. Venezuela. Excepción Preliminar, Fondo, Reparaciones y Costas. Sentencia de 5 de julio de 2006. Serie C N. ${ }^{\circ}$ 150, párr. 141.

34 Caso Caesar Vs. Trinidad y Tobago. Fondo, Reparaciones y Costas. Sentencia 11 de marzo 2005. Serie C N. ${ }^{\circ} 123$, párrs. 132-133. Donde se dijo: «... la Corte considera pertinente ordenar que el Estado enmiende, dentro de un plazo razonable, la mencionada Sección 6 de la Constitución de Trinidad y Tobago, en cuanto imposibilite a las personas el acceso a un recurso efectivo ante un tribunal competente para la protección violaciones de sus derechos humanos».

35 Caso Yatama Vs. Nicaragua. Excepciones Preliminares, Fondo, Reparaciones y Costas. Sentencia de 23 de junio de 2005. Serie C N. ${ }^{\circ}$ 127, párr. 170.

36 Baena Ricardo, op. cit., párr. 183. Destacamos en particular: «En el presente caso, la emisión y aplicación de la Ley 25, con efecto retroactivo, son violatorias de preceptos convencionales y revelan que el Estado no ha tomado las medidas adecuadas de derecho interno para hacer efectivos los derechos consagrados en la Convención. El Estado, al emitir una ley, debe cuidar de que se ajuste a la normativa internacional de protección, y no debe permitir que sea contraria a los derechos y libertades consagrados en un tratado internacional del cual sea Parte». Almonacid Arellano, op. cit., párr. 126.

37 En particular nos referimos al artículo 27 de la Convención de Viena de 1969 sobre Derecho de los Tratados. 
un Estado que ha ratificado un tratado de derechos humanos debe introducir en su derecho interno las modificaciones necesarias para asegurar el fiel cumplimiento de las obligaciones asumidas. La Corte ha señalado en otras oportunidades que esta norma impone a los Estados partes la obligación general de adecuar su derecho interno a las normas de la propia Convención, para garantizar así los derechos consagrados en ésta. Las disposiciones de derecho interno que se adopten para tales fines han de ser efectivas. Lo que significa que el Estado tiene la obligación de consagrar y adoptar en su ordenamiento jurídico interno todas las medidas necesarias para que lo establecido en la Convención sea realmente cumplido y puesto en práctica» ${ }^{38}$.

\subsection{Relación con el Derecho de Acceso a la Justicia}

El derecho a un recurso judicial efectivo, en su relación con el derecho de acceso a la justicia, es de tal amplitud que en propias palabras de la Corte abarca: «... cualquier otra situación que configure un cuadro de denegación de justicia» ${ }^{39}$, por ello no debe concebirse como un derecho que abarca solamente graves y urgentes situaciones, sino a todos los derechos establecidos en la Convención, la Constitución o la ley.

Cantos, op. cit., párr. 59. Destacamos que la Corte en este caso puntual no condenó al Estado por infracción al artículo 2, sin embargo, aleccionadoramente ha dicho en el párr. 62: «No obstante lo anterior, la Corte observa, asimismo, lo siguiente: por una parte, existen normas internas en la Argentina que ordenan liquidar y pagar por concepto de tasa de justicia y de honorarios de abogados y peritos sumas exorbitantes, que van mucho más allá de los límites que corresponderían al cubrimiento razonable de los costos y costas generados por la administración de justicia y a la equitativa remuneración de un trabajo profesional calificado. Por otra parte, también existen disposiciones que facultan a los jueces para reducir el cálculo de la tasa y de los honorarios aludidos a límites que los hagan razonables y equitativos. Es, asimismo, del conocimiento de este Tribunal, que la Suprema Corte de Justicia de Argentina ha invocado la posibilidad de hacer prevalecer en las causas judiciales de orden interno las disposiciones de los tratados internacionales, lo cual ha llevado a que en diversos procesos los jueces hayan aplicado directamente la Convención Americana, modificando, en lo pertinente, los alcances del orden normativo nacional. Así las cosas, este Tribunal no encuentra fundamento para considerar que el Estado ha incumplido el artículo 2 de la Convención porque su orden jurídico, considerado en su integridad, no lleva necesariamente a impedir el acceso a la justicia. En todo caso sería aconsejable que el Estado suprimiera de su ordenamiento jurídico las disposiciones que pudiesen dar lugar, de una u otra manera, a la imposición de tasas de justicia y al cálculo de honorarios que, por ser desmedidas y excesivos, impidieran el cabal acceso a la justicia. Y a su vez adopte el conjunto de medidas tendientes para que la tasa de justicia y el cobro de honorarios no se transformen en obstáculos para hacer efectivos los derechos a las garantías judiciales y a la protección judicial consagrados en la Convención Americana». Caso «La Última Tentación de Cristo» (Olmedo Bustos y otros). Sentencia de 5 de febrero de 2001. Serie C N. ${ }^{\circ}$ 73, párr. 87. Hilaire Constantine, op. cit., párr. 112. Castañeda Gutman, op. cit., párr. 132.

39 Caso Baena Ricardo y otros Vs. Panamá. Competencia. Sentencia de 28 de noviembre de 2003. Serie C N. ${ }^{\circ}$ 104, párr. 77. 19 Comerciantes, op. cit., párr. 192. 
A su vez, el derecho de acceso a la justicia, se configura como un derecho autónomo ${ }^{40}$. Más detalladamente el juez García Ramírez se ha pronunciado sobre lo que el derecho de acceso a la justicia comprende, del siguiente modo: «También se ha ocupado nuestro tribunal en el examen y el pronunciamiento sobre hechos que atañen al acceso a la justicia, o dicho de otro modo, a la preservación y observancia de las garantías judiciales y los medios jurisdiccionales de protección de derechos fundamentales. Ese acceso implica tanto la facultad y la posibilidad de acudir ante órganos que imparten justicia en forma independiente, imparcial y competente, formular pretensiones, aportar o requerir pruebas y alegar en procuración de intereses y derechos (justicia formal), como la obtención de una sentencia firme que satisfaga las exigencias materiales de la justicia (justicia material). Sin esto último, aquello resulta estéril: simple apariencia de justicia, instrumento ineficaz que no produce el fin para el que fue concebido. Es preciso, pues, destacar ambas manifestaciones del acceso a la justicia: formal y material, y orientar todas las acciones en forma que resulte posible alcanzar ambas» ${ }^{41}$.

Una cuestión a determinar, es de qué normas se deriva a juicio de la Corte IDH el derecho de acceso a la justicia. En este sentido nos parece importante recordar que la primera mención a este derecho se produce en el caso Castillo Petruzzi y otros Vs. Perú ${ }^{42}$, pero será en el caso Cantos Vs. Argentina ${ }^{43}$, donde se establece la primera respuesta en la conclusión de que la emanación del Derecho de Acceso a la Justicia deviene tanto de los artículos 8.1 como $25^{44}$.

40 Cinco Pensionistas, op. cit., voto concurrente del juez A. A. Cançado Trindade, párr. 2, donde se dijo: «De la presente Sentencia de la Corte se desprende el amplio alcance del derecho de acceso a la justicia, en los planos tanto nacional como internacional. Tal derecho no se reduce al acceso formal, stricto sensu, a la instancia judicial; el derecho de acceso a la justicia, que se encuentra implícito en diversas disposiciones de la Convención Americana (y de otros tratados de derechos humanos) y que permea el derecho interno de los Estados Partes, significa, lato sensu, el derecho a obtener justicia. Dotado de contenido jurídico propio, configúrase como un derecho autónomo a la prestación jurisdiccional, o sea, a la propia realización de la justicia».

${ }^{41}$ Myrna Mack Chang, op. cit., voto concurrente razonado del juez Sergio García Ramírez, párr. 5.

42 Castillo Petruzzi, op. cit., párr. 128 in fine.

43 Cantos, op. cit., párrs. 50-52.

44 Esto posteriormente fue reiterado en: Castañeda Gutman, op. cit., párr. 100. Y en similar sentido fue expresado en el caso: caso Tiu Tojín Vs. Guatemala. Fondo, Reparaciones y Costas. Sentencia de 26 de noviembre de 2008. Serie C N. ${ }^{\circ}$ 190, párr. 95. También puede verse caso de la Masacre de Pueblo Bello, op. cit., donde el juez Cançado Trinidade en el párr. 34 de su voto razonado trata ambas normas como un todo indisociable del siguiente modo: «O sea, en el entender de la Corte — en una luminosa Opinión Consultiva que hoy constituye un marco en su jurisprudencia y en toda su historia (juntamente con la Opinión Consultiva n. 18 sobre la Condición Jurídica y Derechos de los Migrantes Indocumentados, de 2003) — simplemente no hay debido proceso sin el recurso efectivo ante los jueces o tribunales nacionales competentes, y lo dispuesto en los artículos 25 y 8 de la Corte encuéntrase ineluctablemente vinculado, no sólo en el plano conceptual, sino también —y sobre todo- en el hermenéutico. La Corte 
A su vez, en el caso Barrios Altos Vs. Perú ${ }^{45}$ se menciona el todo indisociable ${ }^{46}$ de los artículos 1.1, 2, 8.1 y 25 con el derecho de acceso a la justicia, en particular sobre las leyes de autoamnistía.

También consideramos pertinente aclarar que en aquellas situaciones donde la Corte IDH se pronuncia sobre el acceso la justicia, la existencia de un recurso judicial efectivo y las debidas garantías en su tramitación, no parten de la arrogación de facultades para inmiscuirse de manera general en la legislación interna del Estado, sino desde una excepcionalidad, al sólo efecto y en los casos donde estos derechos fundamentales establecidos en la Convención se ven violados y no para juzgar sobre las personas procesadas por las violaciones, sino para dilucidar la eventual responsabilidad internacional del Estado por incumplimiento del Pacto ${ }^{47}$.

agregó, en la referida Opinión Consultiva n. 16 sobre El Derecho a la Información sobre la Asistencia Consular en el Marco de las Garantías del Debido Proceso Legal (de 1999), que hay que estar atento para asegurar y para que se pueda constatar que todos los justiciables: disfrutan de un verdadero acceso a la justicia y se benefician de un debido proceso legal [...]» (párr. 119). Barrios Altos, op. cit., párr. 43, donde se dijo: «La Corte estima necesario enfatizar que, a la luz de las obligaciones generales consagradas en los artículos 1.1 y 2 de la Convención Americana, los Estados Partes tienen el deber de tomar las providencias de toda índole para que nadie sea sustraído de la protección judicial y del ejercicio del derecho a un recurso sencillo y eficaz, en los términos de los artículos 8 y 25 de la Convención. Es por ello que los Estados Partes en la Convención que adopten leyes que tengan este efecto, como lo son las leyes de autoamnistía, incurren en una violación de los artículos 8 y 25 en concordancia con los artículos 1.1 y 2 de la Convención. Las leyes de autoamnistía conducen a la indefensión de las víctimas y a la perpetuación de la impunidad, por lo que son manifiestamente incompatibles con la letra y el espíritu de la Convención Americana. Este tipo de leyes impide la identificación de los individuos responsables de violaciones a derechos humanos, ya que se obstaculiza la investigación y el acceso a la justicia e impide a las víctimas y a sus familiares conocer la verdad y recibir la reparación correspondiente». También es importante aclarar que esta postura no es unánime en la Corte IDH, de este modo, la postura del la jueza Medina Quiroga, se encuentra a favor de reservar el artículo 25 al ámbito del recurso de amparo y que su ampliación a otro tipo de vías procesales daría como resultado desvirtuarlo en detrimento de la protección que sobre las víctimas se busca. Gómez Palomino, op. cit., voto concurrente de la jueza C. Medina Quiroga, párr. 5, donde se dijo: «Si esto es así, el incluir en el artículo 25 el derecho a todo tipo de recursos desvirtúa el objetivo original de la norma, en detrimento de las víctimas. Con esto la Corte no se da la oportunidad de elaborar el concepto y los requisitos del recurso de amparo y, de ese modo, dificulta también el identificar qué recursos de amparo propiamente tales deberían existir en el ordenamiento jurídico interno de los Estados Partes de la Convención Americana para salvaguardar los derechos humanos de una manera sencilla, rápida y eficaz». En el mismo sentido y estableciendo la relación de sustancia del artículo 25 a forma del artículo 8: Hermanos Gómez Paquiyauri, op. cit., voto parcialmente disidente de la jueza C. Medina Quiroga, párr. 2.

4719 Comerciantes, op. cit., párr. 181. 


\subsection{Relación con las garantías del debido proceso}

Si se siguen las correlaciones del recurso judicial efectivo dentro de las normas de la Convención, además de ser «pilan» y de interactuar con los principios y obligaciones generales, una de las más directas concordancias la tendrá con el artículo $8.1^{48}$, referido al debido proceso legal.

La Corte IDH, se ha ocupado de establecer que ambas normas guardan una relación directa ${ }^{49}$, donde todo recurso judicial debe cumplir con las garantías del debido proceso ${ }^{50}$ y esto a su vez es condición del cumplimiento del derecho de acceso a la justicia ${ }^{51}$, de las víctimas o de sus familiares.

48 Dice el artículo: «Toda persona tiene derecho a ser oída, con las debidas garantías y dentro de un plazo razonable, por un juez o tribunal competente, independiente e imparcial, establecido con anterioridad por la ley, en la sustanciación de cualquier acusación penal formulada contra ella, o para la determinación de sus derechos y obligaciones de orden civil, laboral, fiscal o de cualquier otro carácter».

49 Loayza Tamayo, op. cit., párr. 169. Castillo Páez, op. cit., párr. 106. Cesti Hurtado, op. cit., párr. 66. Caso Las Palmeras Vs. Colombia. Fondo. Sentencia de 6 de diciembre de 2001. Serie C N. 90, párr. 60. Baldeón García, op. cit., párr. 146. Caso Servellón García y otros Vs. Honduras. Fondo, Reparaciones y Costas. Sentencia de 21 de septiembre de 2006. Serie C N. ${ }^{1}$ 152, párrs. 124 y 148. En cuanto su tratamiento conjunto, destacable es el caso Tristán Donoso Vs. Panamá. Excepción Preliminar, Fondo, Reparaciones y Costas. Sentencia de 27 de enero de 2009 Serie C N. ${ }^{\circ} 193$, párrs. 149-151, donde el Estado fue exonerado del cargo de haber faltado al deber de investigar y sin embargo en la eximición de responsabilidad, la Corte IDH también liga de manera conjunta los artículos comentados.

50 Caso Ximenes Lopes Vs. Brasil. Fondo, Reparaciones y Costas. Sentencia de 4 de julio de 2006. Serie C N. ${ }^{\circ}$ 149, párr. 193. Caso Salvador Chiriboga Vs. Ecuador. Excepción Preliminar y Fondo. Sentencia de 6 de mayo de 2008. Serie C N. ${ }^{\circ}$ 179, párrs. 58-59. Caso Yvon Neptune Vs. Haití. Fondo, Reparaciones y Costas. Sentencia de 6 de mayo de 2008. Serie C N. ${ }^{\circ} 180$, párrs. 82-83, en particular citamos: «... este Tribunal ha señalado que cualquier norma o medida del orden interno que imponga costos o dificulte de cualquier otra manera el acceso de los individuos a los tribunales, y que no esté justificada por las razonables necesidades de la propia administración de justicia, debe entenderse contraria al precitado artículo 8.1 de la Convención». Para continuar diciendo en el párr. 83 que: «En íntima relación con lo anterior, el derecho de acceso a la justicia comprende que desde el inicio toda persona, en caso de ser sometida a un proceso, tenga efectivamente la posibilidad de obtener un pronunciamiento definitivo sin dilaciones indebidas que provengan de la falta de diligencia y cuidado que deben tener los tribunales de justicia, como se ha observado en este caso. En caso contrario, a la luz del derecho a un recurso efectivo, contenido en el artículo 25 de la Convención, es evidente que la persona perseguida no puede hacer valer las garantías contenidas en el artículo 8 de la Convención, las que serían inútiles si fuera imposible comenzar los procedimientos en primer lugar».

5119 Comerciantes, op. cit., párr. 173. En particular y para analizar los hechos destacamos: «No hay lugar a dudas de que la participación que pudieran haber tenido los militares investigados al conocer de las actividades delictivas de grupos al margen de la ley, prestándoles apoyo y cohonestando los acontecimientos delictivos (supra párr. 169) de la detención, la desaparición y la muerte de los 19 comerciantes, así como en la sustracción de sus vehículos y mercancías, no tiene una relación directa con un servicio o tarea militar. Esta Corte considera que la ante- 
Esto $^{52}$ se ha visto en casos donde por ejemplo la falta de independencia e imparcialidad en la tramitación de los recursos presentados, la demora en su resolución, las omisiones en la investigación y su falta general de efectividad conculcaron las garantías de debido proceso legal en conjunto con el recuso judicial efectivo, por lo que a su vez violaron el derecho de acceso a la justicia y como consecuencia se produjo falta de reparación e impunidad de los responsables ${ }^{53}$.

Sobre la relación y deslinde entre estas normas, la Corte IDH históricamente las ha interpretado de forma conjunta en una correspondencia de sustancia y forma, posiblemente porque en numerosos fallos se pronuncia sobre los artículos 8.1 y 25 en referencia y contexto a la violación de otros derechos consagrados en la Convención ${ }^{54}$. Y esto lo ha sostenido en el tiempo.

rior atribución de competencia de la jurisdicción penal militar para conocer de los supuestos delitos perpetrados en perjuicio de los 19 comerciantes por miembros del Ejército, quienes ya estaban siendo investigados por la jurisdicción penal ordinaria, no respetó los parámetros de excepcionalidad y el carácter restrictivo que caracteriza a la jurisdicción castrense, ya que dicha jurisdicción no era competente para conocer de tales hechos, todo lo cual contravino el principio del juez natural que forma parte del derecho a un debido proceso y del derecho de acceso a la justicia, consagrados en los artículos 8.1 y 25 de la Convención Americana».

5219 Comerciantes, op. cit., párr. 187. Donde se dijo: «... el artículo 8.1 de la Convención Americana, en conexión con el artículo 25.1 de la misma, confiere a los familiares de las víctimas el derecho a que la muerte de estas últimas sea efectivamente investigada por las autoridades del Estado; se siga un proceso contra los responsables de estos ilícitos; en su caso, se les impongan las sanciones pertinentes, y se reparen los daños y perjuicios que dichos familiares han sufrido». También: caso Cantoral Huamaní y García Santa Cruz Vs. Perú. Excepción Preliminar, Fondo, Reparaciones y Costas. Sentencia de 10 de julio de 2007. Serie C N. . 167, párr. 191. Caso García Prieto y otros Vs. El Salvador. Excepciones Preliminares, Fondo, Reparaciones y Costas. Sentencia de 20 de noviembre de 2007. Serie C N. ${ }^{\circ}$ 168, párrs. 102-103.

53 Ivcher Bronstein, op. cit., párrs. 138-142. Juan Humberto Sánchez, op. cit., párr. 135. Maritza Urrutia, op. cit., párrs. 118-121. Yvon Neptune, op. cit., párr. 84, en particular citamos: «La Corte considera que este caso se enmarca en una situación de impedimentos normativos y prácticos para asegurar un acceso real a la justicia, así como en una situación generalizada de ausencia de garantías, inseguridad jurídica e ineficacia de las instituciones judiciales para afrontar hechos como los del presente caso. De tal manera, desde el inicio el Estado ha faltado a su obligación de garantizar al señor Neptune su derecho a ser oído por un tribunal competente en la sustanciación de los cargos en su contra, en los términos del artículo 8.1 de la Convención, así como su derecho a un recurso efectivo, protegido por el artículo 25 de la Convención, al no haber tenido acceso sin demora a un tribunal competente». Caso Bayarri Vs. Argentina. Excepción Preliminar, Fondo, Reparaciones y Costas. Sentencia de 30 de octubre de 2008. Serie C N. ${ }^{\circ}$ 187, párr. 117. Caso Ticona Estrada y otros Vs. Bolivia. Fondo, Reparaciones y Costas. Sentencia de 27 de noviembre de 2008. Serie C N. ${ }^{\circ}$ 191, párr. 95. Caso Valle Jaramillo y otros Vs. Colombia. Fondo, Reparaciones y Costas. Sentencia de 27 de noviembre de 2008. Serie C N. ${ }^{\circ}$ 192, párr. 153.

54 Velásquez Rodríguez, op. cit., párr. 90, donde se dijo: «Los Estados Partes se obligan a suministrar recursos judiciales efectivos a las víctimas de violación de los derechos humanos (artículo 25), recursos que deben ser sustanciados de conformidad con las reglas del debido proceso legal (artículo 8.1)...». En el mismo sentido: Fairén Garbi y Solís Corrales, op. cit., párr. 90. Caso 
Pero nos parece a su vez necesario ${ }^{55}$ establecer la precisión entre ellas que la jurisprudencia a hoy no ha hecho con la claridad necesaria a nuestro criterio y sobre este punto creemos interesante la dilucidación de los artículos 25.1 y 8.1 que realiza el juez ad hoc Diego Rodríguez Pinzón en el caso Salvador Chiriboga Vs. Ecuador en su voto parcialmente disidente ${ }^{56}$.

Allí, el honorable magistrado dice que ambas disposiciones por el hecho de estar redactadas en dos artículos diferentes de la Convención nos llevan necesariamente a concebirlas como disposiciones diferentes, porque de lo contrario hubiesen sido escritas en un solo texto integrado ${ }^{57}$.

El artículo 25 hace a la existencia de normas procesales y el artículo 8 refiere al «cómo» dichos procesos deben ser conducidos. Es así que por una parte pueden existir recursos sencillos y rápidos para proteger un derecho, que a su vez no se vean afectados como tales por las prácticas judiciales y resulten efectivos y, sin embargo, el proceso no ha cumplido con las debidas garantías del artículo 8. Ambos derechos pueden ser sujetos de violaciones de forma conjunta o separadamente. La violación del artículo 8 no se traduce en forma automática en la violación del artículo 25.

A su vez, ambas disposiciones son complementarias. Protegen el crucial andamiaje judicial sobre el cual descansa la protección de los derechos humanos reconocidos en la Convención, las constituciones y otras normas nacionales ${ }^{58}$.

Las medidas que el Estado debe adoptar para solventar los problemas en torno a cada artículo son diferentes y complementarias, de esta forma ha dicho el mencionado juez: «Pero más allá del ejercicio semántico está la necesidad de leer

Godínez Cruz Vs. Honduras. Excepciones Preliminares. Sentencia de 26 de junio de 1987. Serie C N. . 3, párr. 92. Corte IDH. Garantías Judiciales en Estados de Emergencia (arts. 27.2, 25 y 8 Convención Americana sobre Derechos Humanos). Opinión Consultiva OC-9/87 del 6 de octubre de 1987. Serie A N. 9 9, párr. 24. Entre otra jurisprudencia.

55 Como ejemplo puede citarse entre otra jurisprudencia: Hilaire Constantine, op. cit., párr. 148, donde se dijo: «Para que se preserve el derecho a un recurso efectivo, en los términos del artículo 25 de la Convención, es indispensable que dicho recurso se tramite conforme a las reglas del debido proceso, consagradas en el artículo 8 de la Convención, incluyendo el acceso a la asistencia letrada».

56 Salvador Chiriboga, op. cit., voto parcialmente disidente del juez ad hoc Diego Rodríguez Pinzón, párrs. 7-13.

57 Ibíd., párr. 10. Este deslinde lo expresa de la siguiente forma: «De una parte, el artículo 25.1 consagra el acceso a recursos sencillos y rápidos u otros recursos ordinarios efectivos, que podrían describirse como los recursos de amparo existentes para proteger ciertos derechos, o los recursos judiciales ordinarios, con la posibilidad de apelaciones, medidas interinas de protección, entre muchas otras, también diseñadas para proteger ciertos derechos. El artículo 8.1, de otra parte, dispone las garantías del debido proceso que deben estar presentes una vez la persona ha tenido acceso a los recursos judiciales en los términos del artículo 25.1». En particular se explaya sobre la relación entre recursos rápidos del artículo 25 , con el «plazo razonable» del artículo 8.

58 Ibíd., párr. 9. 
la Convención en forma sistemática, atendiendo a su propósito y fin, lo cual nos lleva a adoptar aquella interpretación que le da un mayor alcance a las normas que promuevan la mejor protección de los derechos establecidos en la Convención. Esta mejor protección se logra, a mi juicio, enfocando la atención de los Estados en los diferentes momentos de la acción estatal encaminada a estructurar una adecuada protección judicial nacional. Es así como el artículo 2 se refiere al deber de adoptar disposiciones de derecho interno, ya sean legislativas o de otro carácter, para hacer efectivos los derechos y libertades consagrados en la Convención; el artículo 25 establece la necesidad de que exista acceso a la protección judicial de los derechos, ya no limitándose a la mera existencia de normas, sino a la adopción de recursos judiciales adecuadamente articulados para proteger los derechos específicos y a la implementación de prácticas judiciales apropiadas; y el artículo 8.1 dispone la forma como dichos recursos judiciales deben ser adelantados en el caso específico. Los Estados podrán entonces ajustar su conducta a cada uno de estos tres momentos de la protección nacional, evaluando en forma más clara si las normas, recursos, prácticas y procesos judiciales específicos se ajustaron a lo prescrito en cada una de esas normas. De lo contrario, los Estados simplemente se enfocarán en un solo problema general (en este caso la demora injustificada) que violaría en forma indiferenciada el artículo 8.1 y el 25.1, cuando es posible que existan múltiples problemas que afectan a una disposición o a la otra sin que necesariamente tengan que amalgamarse o aplicarse simultáneamente» ${ }^{59}$.

\subsection{Relación con el deber de investigar}

Desde su primer fallo, en el caso Velásquez Rodríguez, el alto tribunal dijo que el deber de investigar se desprende de la obligación general del artículo $1.1^{60}$, en ciertas oportunidades ligándolo de forma directa a situaciones donde ha visto afectado el derecho a la vida e integridad personal ${ }^{61}$. No sólo como obligación positiva sino como deber de prevención desde todos los órganos y agentes del Estado ${ }^{62}$. Y se lo

60 Velásquez Rodríguez, op. cit., párrs. 173-174 y 177.

61 Ximenes Lopes, op. cit., párr. 147. Penal Miguel Castro Castro, op. cit., párr. 253. Cantoral Huamaní y García Santa Cruz, op. cit., párrs. 100 y 102. En el mismo sentido: caso Ríos y otros Vs. Venezuela. Excepciones Preliminares, Fondo, Reparaciones y Costas. Sentencia de 28 de enero de 2009. Serie C N. 194, párr. 283. Caso Perozo y otros Vs. Venezuela. Excepciones Preliminares, Fondo, Reparaciones y Costas. Sentencia de 28 de enero de 2009. Serie C N. ${ }^{0} 195$, párr. 298. Caso Kawas Fernández Vs. Honduras. Fondo, Reparaciones y Costas. Sentencia de 3 de abril de 2009 Serie C N. 196 , párr. 75.

62 Myrna Mack Chang, op. cit., párr. 153. Hermanos Gómez Paquiyauri, op. cit., párr. 129. Huilca Tecse, op. cit., párr.66. En el mismo sentido: Masacre de Pueblo Bello, op. cit., párr. 
ha establecido como una de las condiciones para que pueda cumplirse el pleno goce de los derechos humanos por parte de los particulares ${ }^{63}$.

En otras oportunidades, la vinculación fue realizada por hechos de ejecuciones extrajudiciales y desapariciones forzadas, en conjunto con otras violaciones a los derechos humanos ${ }^{64}$. Así como otras veces se lo ha vinculado en relación a cuestiones estrictamente procesales como puede ser la valoración de la prueba ${ }^{65}$, como aspecto de las garantías judiciales, que de suyo forman parte de las obligaciones generales ${ }^{66}$.

También el deber de investigar ha sido establecido como obligación general en supuestos donde deben resolverse casos que versan sobre crímenes de lesa humanidad ${ }^{67}$.

La omisión de la investigación es una de los artífices de la impunidad y ésta a su vez afecta el pleno goce de derechos establecido en el primer artículo de la Convención ${ }^{68}$.

Toda violación a un derecho de fondo, en la posterior infracción del deber de investigar culmina quedando ligado también al incumplimiento de las obligaciones generales ${ }^{69}$.

Cuando los hechos violatorios a la Convención realizados por particulares o por agentes estatales no son investigados, se propicia dentro de los Estados la repetición

120. Masacres de Ituango, op. cit., párrs. 130-131. Caso Vargas Areco Vs. Paraguay. Fondo, Reparaciones y Costas. Sentencia de 26 de septiembre de 2006. Serie C N. ${ }^{\circ} 155$, párr. 75. Penal Miguel Castro Castro, op. cit., párrs. 237-238.

63 Myrna Mack Chang, op. cit., párr. 153. Comunidad Indígena Sawhoyamaxa, op. cit., párrs. 152-153. Baldeón García, op. cit., párrs. 84-85. Ximenes Lopes, op. cit., párr. 125. Montero Aranguren, op. cit., párrs. 65-66. Caso Zambrano Vélez y otros Vs. Ecuador. Fondo, Reparaciones y Costas. Sentencia de 4 de julio de 2007. Serie C N. ${ }^{\circ}$ 166, párrs. 80-81.

${ }^{64}$ Caso Goiburú y otros Vs. Paraguay. Fondo, Reparaciones y Costas. Sentencia de 22 de septiembre de 2006. Serie C N. ${ }^{\circ} 153$, párr. 88. Caso La Cantuta Vs. Perú. Fondo, Reparaciones y Costas. Sentencia de 29 de noviembre de 2006. Serie C N. ${ }^{\circ}$ 162, párr.110.

65 Niños de la Calle, op. cit., párr. 233.

66 Masacres de Ituango, op. cit., párr. 297. En el mismo sentido: Servellón García, op. cit., párr. 124. Caso Heliodoro Portugal Vs. Panamá. Excepciones Preliminares, Fondo, Reparaciones y Costas. Sentencia de 12 de agosto de 2008. Serie C N. ${ }^{\circ}$ 186, párr. 115.

${ }_{67}$ Almonacid Arellano, op. cit., párr. 110.

68 Caso Garrido y Baigorria Vs. Argentina. Reparaciones y Costas. Sentencia de 27 de agosto de 1998. Serie C N. ${ }^{\circ}$ 39, párr. 173. En el mismo sentido: caso de los «Niños de la Calle» (Villagrán Morales y otros) Vs. Guatemala. Reparaciones y Costas. Sentencia de 26 de mayo de

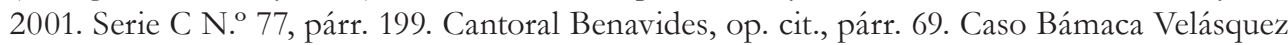
Vs. Guatemala. Reparaciones y Costas. Sentencia de 22 de febrero de 2002. Serie C N. ${ }^{\circ}$ 91, párr. 74. Trujillo Oroza, op. cit., párr. 101. Caso de la Masacre de la Rochela Vs. Colombia. Fondo, Reparaciones y Costas. Sentencia de 11 de de mayo de 2007. Serie C N. ${ }^{\circ}$ 163, párr. 148. Zambrano Vélez, op. cit., párr. 124.

69 Caso Ximenes Lopes Vs. Brasil. Excepción Preliminar. Sentencia de 30 de noviembre de 2005. Serie C N. ${ }^{0} 139$, párr. 147. En similar redacción y a su vez reiterando lo anteriormente dicho: caso de la Masacre de Mapiripán Vs. Colombia. Fondo, Reparaciones y Costas. Sentencia de 15 de septiembre de 2005. Serie C N. ${ }^{\circ} 134$, párrs. 232-234. 
crónica de este tipo de crímenes. Por ello una de las medias más importantes que deben tomar los Estados con miras a erradicar la impunidad, es realizar una investigación efectiva ${ }^{70}$.

A lo largo de su desarrollo jurisprudencial, la Corte IDH se ha referido a la investigación efectiva como una condición sine qua non, para que las personas tengan un verdadero acceso a la justicia.

Es así que además de derivar de las obligaciones generales, como hemos expuesto, el correcto cumplimiento del deber de investigar hace a la observancia de los artículos 8.1 y 25 de la Convención y sus fallas generan impunidad. Esta noción ha sido conceptualizada como que la falta en su conjunto de investigación, persecución, captura, enjuiciamiento y condena de los responsables de las violaciones de los derechos protegidos por la Convención Americana, hace que las víctimas y sus familiares se vean impedidos de acceder a la justicia como único recurso realmente efectivo para incoar una conducta activa por parte del Estado ${ }^{71}$.

En este sentido, en el caso Durand y Ugarte Vs. Perú, se resaltaron los derechos que tienen los familiares de las víctimas de violaciones de derechos humanos en relación al acceso a la justicia.

En las circunstancias que se dieron allí, los señores Durand y Ugarte se encontraban detenidos en un centro penitenciario y desparecieron luego de un operativo en el cual, como consecuencia del uso desmesurado de la fuerza, las autoridades estatales derribaron el pabellón en el que se hallaban las víctimas.

Luego de catorce años de su desaparición, y a pesar de que sus familiares interpusieron los recursos pertinentes, no habían recibido información acerca del paradero y situación de sus seres queridos por parte del Estado.

Teniendo en cuenta estos hechos, la Corte IDH recordó que: «... el artículo 8.1 de la Convención Americana, en conexión con el artículo 25.1 de la misma, confiere a los familiares de las víctimas el derecho a que la desaparición y muerte de estas últimas sean efectivamente investigadas por las autoridades del Estado; se siga un proceso contra los responsables de estos ilícitos; en su caso se les impongan las sanciones pertinentes, y se reparen los daños y perjuicios que dichos familiares han sufrido» ${ }^{72}$.

70 Tibi, op. cit., párr. 159. Un caso anterior donde se alega la Convención es: Panel Blanca, op. cit., párr. 133. Servellón García, op. cit., párrs. 119 y 124. Penal Miguel Castro Castro, op. cit., párrs. 344-345. Caso Bueno Alves Vs. Argentina. Fondo, Reparaciones y Costas. Sentencia de 11 de

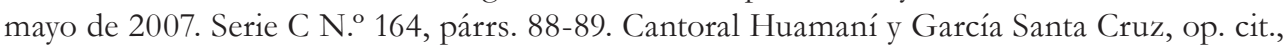
párrs. 100, 102 y 140. Heliodoro Portugal, op. cit., párr. 213. Bayarri, op. cit., párr. 88. Ticona Estrada, op. cit., párr. 94.

71 Panel Blanca, op. cit., párr. 173. Loayza Tamayo, op. cit., párr. 170. Blake, op. cit., párrs. 64-65. Bulacio, op. cit., párr. 120. Cesti Hurtado, op. cit., párrs. 62-64.

72 Durand y Ugarte, op. cit., párr. 130. 
De acuerdo con lo anterior, en casos que abarcan desapariciones forzadas, ejecuciones extrajudiciales o masacres, el alto tribunal ha enfatizado en que: «... toda violación de Derechos Humanos conlleva el deber del Estado de realizar una investigación efectiva para individualizar a las personas responsables de las violaciones y, en su caso, sancionarlas» ${ }^{73}$.

De esta forma, en el caso Bámaca Velásquez Vs. Guatemala, se relacionaron las obligaciones que tiene el Estado en materia de debido proceso, con el derecho a la verdad de quienes fueron afectados por las violaciones a los derechos humanos y de sus familiares. Así se dijo que: «... el derecho a la verdad se encuentra subsumido en el derecho de la víctima o sus familiares a obtener de los órganos competentes del Estado el esclarecimiento de los hechos violatorios y las responsabilidades correspondientes, a través de la investigación y el juzgamiento que previenen los artículos 8 y 25 de la Convención $7^{74}$. Y en esta misma sentencia de reparaciones, la Corte IDH fue más allá señalando que: «... sólo si se esclarecen todas las circunstancias de las violaciones de que se trata se podrá considerar que el Estado ha proporcionado a la víctima y a sus familiares un recurso efectivo y ha cumplido con su obligación general de investigar» ${ }^{75}$.

Más aún, en cumplimiento del deber de esclarecer los hechos violatorios a los derechos humanos que se han presentado dentro de su jurisdicción, los Estados deben observar ciertos límites que permiten que efectivamente se les garanticen los derechos tanto a las víctimas directas de ellos, como a sus familiares.

Es por ello que desde el caso de los 19 Comerciantes Vs. Colombia, en la misma línea de pronunciamientos anteriores ${ }^{76}$, el alto tribunal afirmó que: «El derecho de acceso a la justicia no se agota en que se tramiten procesos internos, sino que debe además asegurar en tiempo razonable, el derecho de la víctima o sus familiares a saber la verdad de lo sucedido y a que se sancione a los eventuales responsables» ${ }^{77}$.

73 Trujillo Oroza, op. cit., párr. 99. En el mismo sentido: caso Del Caracazo Vs. Venezuela. Reparaciones y Costas. Sentencia de 29 de agosto de 2002. Serie C N. ${ }^{\circ}$ 95, párr.115. Bulacio, op. cit., párr. 114. Juan Humberto Sánchez, op. cit., párr. 184. 19 Comerciantes, op. cit., párr. 187.

74 Bámaca Velásquez, op. cit., párr. 201.

75 Ibíd., párr. 75. En el mismo sentido: Trujillo Oroza, op. cit., párr. 109. 19 Comerciantes, op. cit., párr. 176. Ticona Estrada, op. cit., párr. 80.

76 Bulacio, op. cit., párr.114. Myrna Mack Chang, op. cit., párr. 209, donde la Corte IDH señaló que la función de los órganos estatales en la investigación: «... no se agota en posibilitar un debido proceso que garantice la defensa en juicio, sino que debe además asegurar en tiempo razonable, el derecho de la víctima o sus familiares a saber la verdad de lo sucedido y que se sancione a los eventuales responsables».

7719 Comerciantes, op. cit., párr. 188. Hermanas Serrano Cruz, op. cit., párr. 66. Masacre de Mapiripán, op. cit., párr. 216. Masacre de Pueblo Bello, op. cit., párr. 171. Masacres de Ituango, op. cit., párr. 


\subsubsection{Como medio para evitar la impunidad}

Desde su primer fallo, la Corte IDH ha dado los parámetros de la efectividad del recurso judicial, en relación con el cumplimiento del deber de investigar, como medio para evitar la impunidad y esclarecer la verdad a las víctimas y sus familiares. Así ha dicho: «El Estado está, por otra parte, obligado a investigar toda situación en la que se hayan violado los derechos humanos protegidos por la Convención. Si el aparato del Estado actúa de modo que tal violación quede impune y no se restablezca, en cuanto sea posible, a la víctima en la plenitud de sus derechos, puede afirmarse que ha incumplido el deber de garantizar su libre y pleno ejercicio a las personas sujetas a su jurisdicción. Lo mismo es válido cuando se tolere que los particulares o grupos de ellos actúen libre o impunemente en menoscabo de los derechos humanos reconocidos en la Convención» ${ }^{78}$.

El alcance de ese deber ha sido también tratado desde un importante término utilizado y es el de «seriedad», de este modo la investigación: «... debe emprenderse con seriedad y no como una simple formalidad condenada de antemano a ser infructuosa. Debe tener un sentido y ser asumida por el Estado como un deber jurídico propio y no como una simple gestión de intereses particulares, que dependa de la iniciativa procesal de la víctima o de sus familiares o de la aportación privada de elementos probatorios, sin que la autoridad pública busque efectivamente la verdad» ${ }^{79}$.

El deber de investigación posee un alcance de seriedad que va más allá de la formalidad que termina siendo infructuosa de antemano y sin que la autoridad pública busque esclarecer la verdad. Es requisito, entonces, para que no se vean

289. Vargas Areco, op. cit., párr. 101. Penal Miguel Castro Castro, op. cit., párr. 382. La Cantuta, op. cit., párr. 149. Masacre de la Rochela, op. cit., párr. 146. Caso Escué Zapata Vs. Colombia. Fondo, Reparaciones y Costas. Sentencia de 4 de julio de 2007. Serie C N. . 165, párr. 102. Zambrano Vélez, op. cit., párr. 115. Cantoral Huamaní y García Santa Cruz, op. cit., párr. 132.

78 Velásquez Rodríguez, op. cit., párr. 176. En el mismo sentido encontramos el fallo de Godínez Cruz, op. cit., párr. 187.

79 Velásquez Rodríguez, op. cit., párr. 177. Godínez Cruz, op. cit., párr. 188. Suárez Rosero, op. cit., párr. 79. Caso El Amparo Vs. Venezuela. Reparaciones y Costas. Sentencia de 14 de septiembre de 1996. Serie C N. ${ }^{\circ} 28$, párr. 61. Niños de la Calle, op. cit., párr. 226. Durand y Ugarte, op. cit., párr. 123. Bámaca Velásquez, op. cit., párr. 212. Panel Blanca, op. cit., párr. 200. Niños de la Calle, op. cit., párr. 100. Cantoral Benavides, op. cit., párr. 69. Bámaca Velásquez, op. ci., párr. 74. Trujillo Oroza, op. cit., párr. 100. Juan Humberto Sánchez, op. cit., párr. 144. Bulacio, op. cit., párr. 112. Myrna Mack Chang, op. cit., párr. 273. 19 Comerciantes, op. cit., párrs. 184 y 258. Hermanos Gómez Paquiyauri, op. cit., párr. 229. Tibi, op. cit., párr. 256. Masacre Plan de Sánchez, op. cit., párr. 96. Carpio Nicolle, op. cit., párr. 127. Hermanas Serrano Cruz, op. cit., 61 y 168. Caso de la Comunidad Moiwana Vs. Surinam. Excepciones Preliminares, Fondo, Reparaciones y Costas. Sentencia 15 de junio de 2005. Serie C N. ${ }^{\circ}$ 124, párr. 146. Masacre de Mapiripán, op. cit., párr. 223. Gómez Palomino, op. cit., párr. 77. Masacre de Pueblo Bello, op. 
afectados los deberes de los artículos 25 y 8.1 de la Convención, aunque como arriba hemos establecido, este derecho como tal se deriva del artículo 1.1 del Pacto $^{80}$.

Un parámetro concreto de falta de seriedad se ha dado, por ejemplo, en casos de imparcialidad del tribunal que investiga, por ser un fuero militar que debía juzgar a otros militares ${ }^{81}$. O la inacción con todos los medios legales disponibles y sin dilación de la actividad investigativa ex officio del Estado ${ }^{82}$.

En sentido positivo: «La debida diligencia exige que el órgano que investiga lleve a cabo todas aquellas actuaciones y averiguaciones necesarias para procurar el resultado que se persigue» ${ }^{83}$. La consecuencia de la inacción es la impunidad y: «... la Corte recuerda que la impunidad fomenta la repetición de las violaciones de derechos humanos» ${ }^{84}$.

$\mathrm{Al}$ ser el deber de investigar una obligación de medios y no de resultado, si el Estado ha tomado las debidas diligencias ${ }^{85}$ del caso no incurre en responsabilidad internacional, sin embargo, esto no se contradice con la participación y el derecho de audita parte, así como el aceptar los aportes de pruebas que pudieren brindar las víctimas o sus familiares, colaborando con el proceso de manera amplia, y en esta participación también ingresa el derecho a un recurso judicial efectivo para poder intervenir en el proceso ${ }^{86}$.

cit., párr. 143. Baldeón García, op. cit., párr. 93. Ximenes Lopes, op. cit., párr. 148 y 178. Penal Miguel Castro Castro, op. cit., párr. 255. Zambrano Vélez, op. cit., párr. 120. Cantoral Huamaní y García Santa Cruz, op. cit., párr. 131. García Prieto, op. cit., párr. 100. Caso Albán Cornejo y otros. Vs. Ecuador. Fondo Reparaciones y Costas. Sentencia de 22 de noviembre de 2007. Serie C N. ${ }^{\circ}$ 171, párr. 62. Heliodoro Portugal, op. cit., párr. 144. Tiu Tojín, op. cit., párr. 69. Valle Jaramillo, op. cit., párr. 100. Tristán Donoso, op. cit., párr. 146.

${ }^{80}$ Niños de la Calle, op. cit., párr. 225. Bulacio, op. cit., párr. 112. 19 Comerciantes, op. cit., párr. 61. Gómez Palomino, op. cit., párr. 77.

81 Durand y Ugarte, op. cit., párr. 126

82 Comunidad Moiwana, op. cit., párrs. 145-146. Masacre de Mapiripán, op. cit., párr. 77. Masacre de Pueblo Bello, op. cit., párr. 143. Masacres de Ituango, op. cit., párr. 296. Ximenes Lopes, op. cit., párr. 148. Heliodoro Portugal, op. cit., párr. 144.

83 Albán Cornejo, op. cit., párr. 62.

84 Valle Jaramillo, op. cit., párr. 100.

85 En cuanto la debida diligencia en el deber de investigar por parte del Estado ver: Velásquez Rodríguez, op. cit., párr. 172. Caso Las Palmeras Vs. Colombia. Reparaciones y Costas. Sentencia de 26 noviembre de 2002. Serie C N. 96 , párr.68. Molina Theissen, op. cit., párr. 83. Hermanos Gómez Paquiyauri, op. cit., párr. 229. Tibi, op. cit., párr. 259. Hermanas Serrano Cruz, op. cit., párrs. 65 y 83. Masacre Plan de Sánchez, op. cit., párr. 96. Huilca Tecse, op. cit., párr. 108. Gómez Palomino, op. cit., párr. 77. Albán Cornejo, op. cit., párr. 62. Tiu Tojín, op. cit., párr. 76.

86 Baldeón García, op. cit., párr. 93. Penal Miguel Castro Castro, op. cit., párr. 255. Zambrano Vélez, op. cit., párr. 120. 


\section{Contenido del derecho a un recurso judicial efectivo}

Sobre el contenido del artículo 25 de la Convención, mucho ha dicho la Corte IDH, en especial en sus relaciones con los artículos 1.1, 2 y 8 del mismo cuerpo, que acabamos de exponer. Cierto sector de la doctrina lo ha calificado como un derecho subjetivo ${ }^{87}$.

En las primeras páginas de este trabajo hemos en parte delineado la relación e independencia en el Sistema Interamericano del derecho de acceso a la justicia, derecho de acceso a un recurso judicial efectivo y el deber de cumplimiento de las garantías procesales.

A su vez se ha dicho que el artículo 25 no se circunscribe a una relación ritual o formal respecto del derecho general de acceso a la justicia, sino que como derecho humano es per se un derecho autónomo ${ }^{88}$.

El apartado segundo del artículo $25^{89}$, establece las obligaciones del Estado con respecto al recurso judicial efectivo. Deber que puede resumirse diciendo que el Estado debe brindar las condiciones para que el recurso pueda ser desarrollado, donde destacamos que esto incluye el efectivo cumplimiento de la sentencia ${ }^{90}$.

El ámbito de aplicación del artículo 25 de la Convención es el de garantizar que los Estados, como deber positivo, otorguen recursos efectivos para la salvaguarda de los derechos y encuentra su primer fundamento en las obligaciones generales consagradas en los artículos 1.1 y 2 del Pacto ${ }^{91}$.

Por una parte la función de los recursos estará centrada en el amparo de los derechos fundamentales no susceptibles de suspensión ${ }^{92}$, en especial ante situaciones

87 Su fundamentación, así como estudio comparado, puede verse en: O’Donell, Daniel. Derecho internacional de los Derechos Humanos - Normativa, jurisprudencia y doctrina de los sistemas universal e Interamericano, Bogotá, Alejandro Valencia Villa, 2004, óp. cit., págs. 470 y ss. Cantos, op. cit., párr. 52.

89 Dice la norma: «2. Los Estados Partes se comprometen: a) a garantizar que la autoridad competente prevista por el sistema legal del Estado decidirá sobre los derechos de toda persona que interponga tal recurso; b) a desarrollar las posibilidades de recurso judicial, y c) a garantizar el cumplimiento, por las autoridades competentes, de toda decisión en que se haya estimado procedente el recurso».

90 El específico desarrollo de este punto implicaría explayarnos sobre los requisitos, cuestión que en la introducción hemos comentado que por razones de objeto y extensión dejaremos para posteriores escritos.

91 Excepciones al Agotamiento de los Recursos Internos (arts. 46.1, 46.2.a y 46.2.b, Convención Americana sobre Derechos Humanos). Opinión Consultiva OC-11/90 del 10 de agosto de 1990. Serie A N. ${ }^{\circ} 11$, párr. 34. Y toda la jurisprudencia sobre este punto arriba citada.

92 Sobre eso no nos son ajenas las posturas que consideran que el artículo 25 se reduce al recurso de amparo para la protección de derechos fundamentales y los otros aspectos se derivarían de 
emergencia o de declaración de estado de excepción ${ }^{93}$, también llamado de sitio, abarcando todo derecho también reconocido en la Convención, la Constitución o la ley ${ }^{94}$, lo que en concordancia y conjunción con el alcance amplio que se le ha dado implica que es el canal procesal por el cual se hace efectiva la protección de los derechos en el reclamo judicial ante su posible conculcación.

\section{Alcance del derecho a un recurso judicial efectivo}

El alcance de la protección otorgada por el artículo 25 de la Convención ha sido establecido, bajo un criterio amplio, como deber por parte del Estado ${ }^{95}$. Por ello la indefensión a la que se ve sujeta la víctima por la inexistencia, inefectividad o ineficacia de un recurso judicial contra actos violatorios de sus derechos fundamentales, no

otras normas dentro de la Convención, esencialmente en las obligaciones generales de los artículos 1.1 y 2. Creemos que es destacable tener en cuenta las referencias de los diferentes votos razonados de la jueza Medina Quiroga, entre los que se puede citar: Gómez Palomino, op. cit., voto concurrente de la jueza Quiroga Medina.

93 Sobre el tema, en cuanto profundización doctrinaria puede consultarse: Arias Ávila, Néstor Oswaldo. El tratamiento internacional de la suspensión de garantías judiciales en los estados de excepción, Bogotá, Escuela Superior de Administración Pública, 1993, 156 págs. También: Córdoba Z., Francisco. La carta de derechos y la jurisprudencia de la Corte Interamericana, Bogotá, Editorial Temis S. A., 1994, 217 págs., págs. 74 y ss; y López Guerra, Luis. «Derechos fundamentales y estados de excepción», en Nieto Navia, Rafael ed. La Corte y el Sistema Interamericanos de Derechos Humanos, San José, Corte Interamericana de Derechos Humanos, 1994, págs. 279 a 297.

94 Garantías Judiciales en Estados de Emergencia (arts. 27.2, 25 y 8 Convención Americana sobre Derechos Humanos). Opinión Consultiva OC-9/87 del 6 de octubre de 1987. Serie A N. ${ }^{\circ} 9$, párr. 23., donde se dijo: «Como ya lo ha señalado la Corte, el artículo 25.1 de la Convención es una disposición de carácter general que recoge la institución procesal del amparo, como procedimiento sencillo y breve que tiene por objeto la tutela de los derechos fundamentales (El habeas corpus bajo suspensión de garantías, supra 16, párr. 32). Establece este artículo, igualmente, en términos amplios, la obligación a cargo de los Estados de ofrecer, a todas las personas sometidas a su jurisdicción, un recurso judicial efectivo contra actos violatorios de sus derechos fundamentales. Dispone, además, que la garantía allí consagrada se aplica no sólo respecto de los derechos contenidos en la Convención, sino también de aquéllos que estén reconocidos por la Constitución o por la ley. De donde se concluye, a fortiori, que el régimen de protección judicial dispuesto por el artículo 25 de la Convención es aplicable a los derechos no susceptibles de suspensión en estado de emergencia». Esta opinión se condice con la exigencia de la Convención de un Recurso Judicial Efectivo, para la protección de los derechos fundamentales, remarcada en la jurisprudencia de los casos: Tribunal Constitucional, op. cit., párr. 89. Comunidad Mayagna (Sumo) Awas Tingni, op. cit., párr. 111. Cantos, op. cit., párr. 52. Yatama, op. cit., párr. 167. Caso Claude Reyes y otros Vs. Chile. Fondo, Reparaciones y Costas. Sentencia de 19 de septiembre de 2006. Serie C N. ${ }^{\circ}$ 151, 128. Caso Trabajadores Cesados del Congreso (Aguado Alfaro y otros) Vs. Perú. Excepciones Preliminares, Fondo, Reparaciones y Costas. Sentencia de 24 de noviembre de 2006. Serie C N. 158, párr. 122. Salvador Chiriboga, op. cit., párr. 57. Bayarri, op. cit., párr. 102.

95 Caso Palamara Iribarne Vs. Chile. Fondo, Reparaciones y Costas. Sentencia de 22 de noviembre de 2005. Serie C N. ${ }^{\circ}$ 135, párr. 183. Acosta Calderón, op. cit., párr. 92. Caso García Asto y 
sólo se circunscribe a los derechos contenidos en la Convención, sino también: «... de aquéllos que estén reconocidos por la Constitución o por la ley» ${ }^{96}$.

El derecho consagrado en el artículo 25 de la Convención es la posibilidad real de acceder a un recurso judicial efectivo. Posee una relación directa con los artículos 1.1, 2 y 8 en cuanto derecho de acceso a la justicia y allende las razones de fondo alegadas o de la violación concreta de un derecho sustancial consagrado en la Convención, la Constitución o las leyes internas, su infracción constituye de por sí una violación al Pacto, al haber sido establecido como un derecho autónomo.

El Estado no puede saber de forma previa si se ha violado un derecho de fondo, lo que dicho en otras palabras, viene a significar que se debe garantizar el acceso y la efectividad de los medios judiciales a través de los cuales un ciudadano puede alegar una presunta violación de sus derechos. La decisión resultante de este proceso a favor o en contra de lo reclamado es independiente de la obligación de garantizar el recurso. No se puede exigir al justiciable que antes de que interponga el recurso se asegure que su causa será admitida y fallada a su favor, entonces de allí se deriva la independencia del derecho a un recurso judicial efectivo, respecto de los demás derechos consagrados en la Convención. De esta forma es posible que solamente sea violado el artículo 25 y no se prueba la violación de ningún otro derecho, así, ha dicho textualmente la Corte IDH que: «Sería irrazonable establecer dicha garantía judicial si se exigiera a los justiciables saber de antemano si su situación será estimada por el órgano judicial como amparada por un derecho específico» ${ }^{97}$. Es por ello que todo posee una interpretación sistémica orientada a: «... la posibilidad real de acceder a un recurso judicial para que la autoridad competente y capaz de emitir una decisión vinculante determine si ha habido o no una violación a algún derecho que la persona que reclama estima tener y que, en caso de ser encontrada una violación, el recurso sea útil para restituir al interesado en el goce de su derecho y repararlo» ${ }^{98}$.

Veamos entonces la configuración de algunos aspectos puntuales de su alcance.

Ramírez Rojas Vs. Perú. Excepción Preliminar, Fondo, Reparaciones y Costas. Sentencia de 25 de noviembre de 2005. Serie C N. ${ }^{\circ}$ 137, párr. 113.

96 Tribunal Constitucional, op. cit., párr. 89. Caso «Instituto de Reeducación del Menor»Vs. Paraguay. Excepciones Preliminares, Fondo, Reparaciones y Costas. Sentencia de 2 de septiembre de 2004. Serie C N. ${ }^{\circ} 112$, párr. 239. Yatama, op. cit., párr. 167. C N. ${ }^{\circ}$ 114, párr. 130. Claude Reyes, op. cit., párr. 129.

97 Castañeda Gutman, op. cit., párr. 100.

98 Ibíd., párr. 100. 


\subsection{Como derecho no absoluto}

La jurisprudencia interamericana ha referido el alcance de este derecho dentro de las «razonables necesidades de administración de justicia»", así, también la Corte IDH ha establecido que el derecho a un recurso judicial efectivo no es absoluto ${ }^{100} \mathrm{y}$ puede estar sujeto a limitaciones.

De este modo en el caso Cantos Vs. Argentina, se estableció que es facultativo por parte del Estado fijar el pago de tasas para el acceso a la justicia, sin embargo: «... éstas deben guardar correspondencia entre el medio empleado y el fin perseguido y, en definitiva, no pueden suponer la negación misma de dicho derecho» ${ }^{101}$.

Ante todo, las restricciones normativas internas no pueden contravenir obligaciones internacionales.

Concretamente en el mencionado caso, las sumas que debían pagarse como gastos judiciales y tasas, más los honorarios de los abogados, resultaban excesivas y si bien guardaban una relación porcentual con el pleito acorde con las leyes internas, culminaban resultando desproporcionadas y las consecuencias de haber recurrido a la justicia terminaban siendo el embargo de los bienes del actor y quitarle las posibilidades de ejercer el comercio por parte de las autoridades ${ }^{102}$.

99 Yvon Neptune, op. cit., párrs. 82-83. Donde se referencia de forma directa el caso Cantos, op. cit., párr. 50. Recordamos que en el caso Yvon Neptune Vs. Haití la víctima se encontró inmersa en una serie de impedimentos normativos y prácticos que imposibilitaron su efectivo acceso a la justicia ante el proceso penal en su contra.

$100 \mathrm{Si}$ se desea ver un análisis doctrinal del concepto de absoluto en los derechos fundamentales en el Sistema Interamericano, puede consultarse: BRAGUE CAMAZANO, Joaquín. Los límites a los derechos fundamentales, Madrid, Dykinson S. L., 2004. CIANCIARDO, Juan. El conflictivismo en los derechos fundamentales, 2. ed. actualizada y ampliada, Pamplona, Eunsa, 2000; y del mismo autor: El ejercicio regular de los derechos. Análisis y crítica del conflictivismo, Buenos Aires, Ad-Hoc, 2007; TOLLER, Fernando. «Propuestas para un nuevo modelo de interpretación en la resolución de conflictos entre derechos constitucionales», en Anuario de Derecho de la Universidad Austral, n. ${ }^{\circ}$ 4, Buenos Aires, 1998, págs. 225 a 252; SERNA, Pedro; TOLLER Fernando. La interpretación constitucional de los derechos fundamentales. Una alternativa a los conflictos de derechos, Buenos Aires, La Ley, 2000.

101 Cantos, op. cit., párr. 54. Si bien en este caso la Argentina probó la proporcionalidad porcentual de la tasa de justicia a cobrarse y alegó que la norma de derecho interno tendía a impedir demandas temerarias, la Corte contestó que: «... el monto por cobrar en el caso en estudio no guarda relación entre el medio empleado y el fin perseguido por la legislación argentina, con lo cual obstruye, evidentemente, el acceso a la justicia del señor Cantos, y en conclusión viola los artículos 8 y 25 de la Convención».

102 Ibíd., párr. 55 


\subsection{Como respuesta en un plazo razonable}

La Corte IDH ha establecido la íntima relación entre el proceso y el fondo, como mínimo en una respuesta a lo reclamado de manera fundamentada y en tiempo razonable, por ello: «El derecho de acceso a la justicia no se agota en que se tramiten procesos internos, sino que debe además asegurar en tiempo razonable, el derecho de la víctima o sus familiares a saber la verdad de lo sucedido y a que se sancione a los eventuales responsables» ${ }^{103}$. Situación que es extensible a todo tipo de fuero, porque todos los órganos del Estado y en ellos las personas que ejercen funciones públicas, poseen el deber de respeto a los derechos fundamentales ${ }^{104}$.

A partir del caso Apitz Barbera y otros («Corte Primera de lo Contencioso Administrativo») Vs. Venezuela ${ }^{105}$, la Corte IDH ha dejado claro que la rapidez del recurso judicial es un requisito propio y diferente del derecho a que resuelva en plazo razonable la causa concretamente y, entre otras cosas, se dijo que: «En razón de lo anterior, la Corte debe hacer un análisis que diferencie la duración del amparo de la duración del recurso de nulidad que, aunque ejercidos conjuntamente, tienen fines distintos. Así, la Corte considera que el amparo debe ser "sencillo y rápido", en los términos del artículo 25.1 de la Convención, mientras que la nulidad debe resolverse en un "plazo razonable", conforme al artículo 8.1 de la misma» ${ }^{106}$.

De esta forma, la ausencia de celeridad e inmediatez en la resolución de una medida de amparo interpuesta hace a la violación del artículo 25.1 del Pacto. Y, por otra parte, la ausencia de resolución sobre el recurso de nulidad del caso de marras a partir de los parámetros que a continuación citaremos, hace a la violación de la garantía consagrada en el artículo 8.1 de la Convención ${ }^{107}$.

Entonces, uno de los enclaves de lo dicho es determinar las medidas del tiempo razonable en el que se desarrolla el proceso, para ello la Corte IDH dice que se debe evaluar la: «... a) complejidad del asunto, b) actividad procesal del interesado y c) conducta de las autoridades judiciales. No obstante, la pertinencia de aplicar esos tres criterios para determinar la razonabilidad del plazo de un proceso depende de las circunstancias de cada caso» ${ }^{108}$. A estos criterios, a partir del caso Valle Jaramillo

103 Trujillo Oroza, op. cit., párr. 109. 19 Comerciantes, op. cit., párr. 188. Hermanas Serrano Cruz, op. cit., párr. 66. Masacre de Mapiripán, op. cit., párr. 216.

10419 Comerciantes, op. cit., párr. 188. Masacre de Mapiripán, op. cit., párr. 216. Hermanas Serrano Cruz, op. cit., párr. 66. Palamara Iribarne, op. cit., párr. 188.

105 Apitz Barbera, op. cit., párrs. 162-181.

106 Ibíd., párr. 170

107 Ibíd., párrs. 171-172.

108 Caso Genie Lacayo Vs. Nicaragua. Fondo, Reparaciones y Costas. Sentencia de 29 de enero de 1997. Serie C N. ${ }^{\circ}$ 30, párr. 77. Donde se toman estos tres elementos a partir del homólogo 
y otros Vs. Colombia, se adicionó un cuarto elemento ${ }^{109}$, consistente en la: «... afectación actual que el procedimiento implica para los derechos y deberes - es decir, la situación jurídica - del individuo» ${ }^{110}$. La referencia a lo actual se establece como contraria a probable, eventual o remota. Y su precisión se realiza, de igual manera que los otros parámetros enunciados, dentro del caso concreto y sus circunstancias, todas en su conjunto ${ }^{111}$.

Ya sea en los recursos específicos de amparo y hábeas corpus, en relación al Recurso Judicial Efectivo, o en el plazo razonable derivado de la garantía fundamental establecida en el artículo 8, el momento en que se evalúa el plazo razonable es en cada caso.

El criterio que se toma también depende de la vía procesal que corresponda para la defensa del derecho conculcado y el cuarto elemento mencionado ingresa a partir de la posibilidad de que se esté cumpliendo con los parámetros anteriores y sin embargo el transcurso del tiempo esté produciendo una afectación actual en un derecho fundamental del individuo. Esto se analizará desde la diversidad y complejidad de legislaciones rituales que para cada derecho establece cada Estado.

\subsection{Deber de cumplimiento de las sentencias}

La realización de la justicia se encuentra centrada en la efectividad del proceso ${ }^{112}$ y ésta, en último término, en el reconocimiento o ejecución de la pretensión que el fallo dicta, lo contrario es la negación del derecho. Dicho de otro modo, el derecho de acceso a un recurso judicial efectivo supone la materialización del resultado obtenido.

tribunal europeo en su jurisprudencia y que se reproducen a su vez en: Suárez Rosero, op. cit., párr. 72. Hilaire Constantine, op. cit., párr. 143. 19 Comerciantes, op. cit., párr. 190. Caso Ricardo Canese Vs. Paraguay. Fondo, Reparaciones y Costas. Sentencia de 31 de agosto de 2004. Serie C N. 111, párr. 141. Tibi, op. cit., párr. 175. Hermanas Serrano Cruz, op. cit., párr. 67. Comunidad Indígena Yakye Axa, op. cit., párr. 65. Acosta Calderón, op. cit., párr. 105. Masacre de Mapiripán, op. cit., párr. 217. García Asto y Ramírez Rojas, op. cit., párr. 166. Masacre de Pueblo Bello, op. cit., párr. 170. López Álvarez, op. cit., párr. 132. Baldeón García, op. cit., párr. 151. Masacres de Ituango, op. cit., párr. 289. Ximenes Lopes, op. cit., párr. 196. Vargas Areco, op. cit., párr. 102. La Cantuta, op. cit., párr. 149. Escué Zapata, op. cit., párr. 102. Heliodoro Portugal, op. cit., párr. 149. Valle Jaramillo, op. cit., párr. 155.

109 López Álvarez, op. cit., voto razonado del juez Sergio García Ramírez, párr. 29. Comunidad Indígena Sawhoyamaxa, op. cit., voto razonado del juez Sergio García Ramírez, párr. 7. Masacres de Ituango, op. cit., voto razonado del juez Sergio García Ramírez, párr. 26. Valle Jaramillo, op. cit., voto concurrente del juez Sergio García Ramírez, párrs. 9-14.

110 López Álvarez, op. cit., voto razonado del juez Sergio García Ramírez, párr. 29.

111 Ibíd., voto razonado del juez García Ramírez, párr. 37.

112 Sobre el tema puede verse: Ciuro Caldani, Miguel Ángel. Estudios de filosofía del derecho internacional privado, Rosario, Fundación para las Investigaciones Jurídicas, 1997, pág. 7 y ss. Feuillade, Milton C. Cooperación jurisdiccional internacional, Buenos Aires, Ábaco de Rodolfo Depalma, en prensa. 
En este orden de cosas, la Corte IDH ha dicho que: «La efectividad de las sentencias depende de su ejecución. El proceso debe tender a la materialización de la protección del derecho reconocido en el pronunciamiento judicial mediante la aplicación idónea de dicho pronunciamiento. El cumplimiento de las sentencias está fuertemente ligado al derecho de acceso a la justicia, el cual se encuentra consagrado en los artículos 8 (Garantías Judiciales) y 25 (Protección Judicial) de la Convención Americana.» ${ }^{113}$.

Por ello: «... la responsabilidad estatal no termina cuando las autoridades competentes emiten la decisión o sentencia. Se requiere, además, que el Estado garantice los medios para ejecutar dichas decisiones definitivas» ${ }^{114}$. En razón de esto la garantía del recurso judicial efectivo culmina con la realización del derecho en la realidad concreta, la ejecución de las sentencias es parte del derecho de acceso a la justicia en sentido amplio, y es parte del juicio.

Todo lo dicho, el Tribunal Interamericano a su vez, lo traslada al proceso internacional y la obligatoriedad del cumplimiento de sus sentencias, bajo pena de la responsabilidad internacional del Estado ${ }^{115}$, sin que esto en ningún aspecto implique arrogaciones de instancia supranacional por parte de la Corte IDH.

En este sentido, también es dable aclarar que no es lícito al Estado, en materia de vulneración de derechos fundamentales y en particular de derecho de acceso a un recurso judicial efectivo, alegar razones de plaza y presupuesto como excusa lícita de incumplimiento ${ }^{116}$.

\subsection{Necesidad de motivación de las decisiones}

Las decisiones de carácter jurisdiccional que tomen los órganos del Estado, deben estar debidamente fundamentadas, bajo la consecuencia de incurrir en arbitrariedad, en particular aquéllas que puedan afectar a los derechos humanos.

Cuando anteriormente nos referimos a órganos del Estado, es en el sentido de que la debida fundamentación de las decisiones no se reduce a las emanadas del Poder Judicial, ya sea ordinario o en alguno de sus fueros especiales, sino que abarca a las resoluciones de carácter jurisdiccional que pudieren tomar otros poderes, como por ejemplo el Ejecutivo ${ }^{117}$.

113 Baena Ricardo, op. cit., párrs. 73-74. Y su antecedente en el caso: Cinco Pensionistas, op. cit., párr. 126.

114 Baena Ricardo, op. cit., párr. 79.

115 Ibíd., párr. 83. Aparte, paradigmático y triste caso insignia en este punto en cuanto incumplimiento de las resoluciones internas e internacionales puede verse en el fallo: Instituto de Reeducación del Menor, op. cit., párrs. 248-250.

116 Acevedo Jaramillo, op. cit., párrs. 216-220 y en especial el 225.

117 Claude Reyes, op. cit., párr. 118. En este caso se ve claramente la condena por la negativa del vicepresidente ejecutivo del Comité de Inversiones Extranjeras de otorgar información de forma 
En especial la fundamentación de los fallos, cuando refieran cuestiones que pudieren afectar derechos humanos, debe no sólo estar acorde con el derecho interno, sino con el derecho convencional en la materia.

Sobre el concepto o alcance del término «fundamentación», ha dicho la Corte IDH, en el caso Claude Reyes y otros Vs. Chile, en referencia a la respuesta judicial sobre el derecho de acceso a la información, en el momento de tratar las violaciones a los artículos 25 y 8.1, que el fallo debe: «... permitir conocer cuáles fueron los motivos y normas en que se basó para no entregar parte de la información en el caso concreto y determinar si tal restricción era compatible con los parámetros dispuestos en la Convención» ${ }^{118}$.

A partir de esto, también se ha explicitado lo que debe entenderse por motivos o motivación, habiéndose dicho que: «... la motivación "es la exteriorización de la justificación razonada que permite llegar a una conclusión". El deber de motivar las resoluciones es una garantía vinculada con la correcta administración de justicia, que protege el derecho de los ciudadanos a ser juzgados por las razones que el Derecho suministra, y otorga credibilidad de las decisiones jurídicas en el marco de una sociedad democrática» ${ }^{119}$.

Los fundamentos de una sentencia hacen a su debida argumentación y ésta posee la obligación de demostrar que: «... han sido debidamente tomados en cuenta los alegatos de las partes y que el conjunto de pruebas ha sido analizado» ${ }^{120}$.

Ejemplo paradigmático de lo que venimos diciendo se encuentra en el caso Yvon Neptune Vs. Haití, donde la víctima había sido ya liberada de la prisión preventiva a la que se había visto sometida, pero la sentencia fue arbitraria, porque los motivos

fundamentada y la consecuencia de esta arbitrariedad fue el conculcamiento de los derechos de libertad de pensamiento y expresión.

118 Claude Reyes, op. cit., párrs. 122 y 137, donde se dijo: «El Estado debe garantizar que, ante la denegatoria de información bajo el control estatal, exista un recurso judicial sencillo, rápido y efectivo que permita que se determine si se produjo una vulneración del derecho del solicitante de información y, en su caso, se ordene al órgano correspondiente la entrega de la información. En este ámbito, dicho recurso debe ser sencillo y rápido, tomando en cuenta que la celeridad en la entrega de la información es indispensable en esta materia. De acuerdo a lo dispuesto en los artículos 2 y 25.2.b) de la Convención si el Estado Parte en la Convención no tiene un recurso judicial para proteger efectivamente el derecho tiene que crearlo». A su vez la respuesta como condición de efectividad y garantía procesal debe ser fundamentada, cosa que no ocurrió en el caso.

119 Apitz Barbera, op. cit., párr. 77. Más adelante, en el párr. 78, como mayor clarificación del con cepto se dice: «... la motivación demuestra a las partes que éstas han sido oídas y, en aquellos casos en que las decisiones son recurribles, les proporciona la posibilidad de criticar la resolución y lograr un nuevo examen de la cuestión ante las instancias superiores. Por todo ello, el deber de motivación es una de las "debidas garantías" incluidas en el artículo 8.1 para salvaguardar el derecho a un debido proceso».

120 Ibíd., párr. 78 
de la decisión fueron por razones humanitarias y no por una fundamentación que definiera su responsabilidad por los hechos que se le imputaban y la consecuencia era a su vez que se podía continuar con la persecución penal por esos hechos ${ }^{121}$.

\subsection{Situaciones de denegación de justicia}

Las situaciones de denegación de justicia, poseen en palabras de la Corte IDH una relación directa con el artículo 25, así: «El derecho a la tutela judicial efectiva exige a los jueces que dirijan el proceso en forma que eviten dilaciones y entorpecimientos indebidos que conduzcan a la impunidad, frustrando así la debida protección judicial de los derechos humanos» ${ }^{122}$.

En este punto se puede partir de situaciones extremas de persecuciones y de denegación de justicia, por medio de denuncias civiles y penales, donde existe una acción positiva del Estado en la perpetración de los hechos ${ }^{123 .}$

Pero también toda acción pasiva del Estado, bajo la excusa de retardo injustificado de la decisión ${ }^{124}$ o la falta de medios para la ejecución de ella, configuran supuestos de responsabilidad, por tornar ilusorio el acceso al recurso judicial efectivo, porque la inutilidad termina quedando demostrada por la práctica o por la falta de imparcialidad de los magistrados ${ }^{125}$. Esta pasividad como infracción abarca tanto las etapas ejecutivas como las investigativas ${ }^{126}$.

Como ya hemos mencionado, este punto es de tal amplitud que como ya se ha citado y en propias palabras de la Corte IDH abarca: «... cualquier otra situación que configure un cuadro de denegación de justicia» ${ }^{127}$ y esta literalidad se conjuga con la diversidad de hechos en los que el alto tribunal ha dicho lo mismo, por

121 Yvon Neptune, op. cit., párr. 75.

122 Bayarri, op. cit., párr. 116. En el caso de marras se trataba de una tramitación penal que llevaba diecisiete años, ver en especial párrs. 114-115. Y otro ejemplo de proceso penal llevado adelante durante veinticinco años y archivado durante once puede verse en Ticona Estrada, op. cit., párr. 82.

123 Tal como ocurrió en Ivcher Bronstein, op. cit., párr. 141, donde se atentó contra un empresario de medios de comunicación.

124 Existe una relación entre el retardo injustificado y el derecho de acceso a la justicia y su aspecto de efectividad, así por ejemplo en Salvador Chiriboga, op. cit., párr. 87, al momento de plantear su denuncia hacía diez años que esperaba que la justicia se pronuncie sobre la indemnización que le correspondía por la expropiación de un inmueble. También, si se trata de un proceso penal y se ordena su reapertura, el excesivo plazo afecta el derecho de acceso a la justicia, tal es el supuesto del caso Heliodoro Portugal, op. cit., párr. 156.

125 Castillo Petruzzi, op. cit., párr. 185. Comunidad Mayagna (Sumo) Awas Tingni, op. cit., párr. 113. Las Palmeras, op. cit., párr. 58. Cinco Pensionistas, op. cit., párr. 126. Baena Ricardo, op. cit., párr. 77. Acevedo Jaramillo, op. cit., párr. 213.

126 Zambrano Vélez, op. cit., párr. 126.

127 Baena Ricardo, op. cit., párr. 77. 19 Comerciantes, op. cit., párr. 192. 
ello no debe pensarse como un principio que abarca solamente graves y urgentes situaciones, sino a todos los derechos establecidos en la Convención.

A su vez, se han establecido supuestos de hechos independientes a lo largo del proceso que pueden configurar violaciones específicas y autónomas de denegación de justicia ${ }^{128}$, por ejemplo: «... la decisión de un juez de no permitir la participación del defensor del acusado en el proceso; la prohibición a los defensores de entrevistarse a solas con sus clientes, conocer oportunamente el expediente, aportar pruebas de descargo, contradecir las de cargo y preparar adecuadamente los alegatos; la actuación de jueces y fiscales «sin rostro», el sometimiento al acusado a torturas o maltratos para forzar una confesión; la falta de comunicación al detenido extranjero de su derecho de asistencia consular y la violación del principio de coherencia o de correlación entre acusación y sentencia, entre otros» ${ }^{129}$.

Veamos ahora algunas situaciones puntuales donde se ha fallado sobre el tema:

\subsubsection{Acción directa de agentes estatales}

Si la obstaculización fue perpetrada por agentes públicos se acrecienta la responsabilidad internacional del Estado, en este sentido se ha dicho: «Los funcionarios públicos y los particulares que entorpezcan, desvíen o dilaten indebidamente las investigaciones tendientes a aclarar la verdad de los hechos, deberán ser sancionados, aplicando al respecto, con el mayor rigor, las previsiones de la legislación interna» ${ }^{130}$.

\subsubsection{Falta de respuesta estatal como indicio grave}

La demora en la respuesta por parte del Estado ha sido tomada como un indicio grave a la hora de evaluarse infracciones al recurso judicial efectivo. En palabras textuales citamos: «Para la Corte la falta de respuesta estatal es un elemento determinante al valorar si se ha dado un incumplimiento del contenido de los artículos 8.1 y 25.1 de la Convención Americana, pues tiene relación directa con el principio de efectividad que debe irradiar el desarrollo de tales investigaciones. De tal forma el Estado al recibir una denuncia penal, debe realizar una investigación seria e imparcial, pero también debe brindar en un plazo razonable una resolución que resuelva el fondo de las circunstancias que le fueron planteadas» ${ }^{131}$.

128 García Prieto, op. cit., párr. 43.

${ }^{129}$ Almonacid Arellano, op. cit., párr. 48. García Prieto, op. cit., párr. 12.

${ }^{130}$ Caracazo, op. cit., párr. 119. Hermanas Serrano Cruz, op. cit., párr. 173. Gutiérrez Soler, op. cit., párr. 97. Gómez Palomino, op. cit., párr. 140. Masacres de Ituango, op. cit., párr. 402. Montero Aranguren, op. cit., párr. 141.

131 García Prieto, op. cit., párr. 115. Heliodoro Portugal, op. cit., párr. 157. 


\subsubsection{Alegación de disposiciones de amnistía o prescripción}

Toda invocación desde el derecho interno de leyes de amnistía o autoamnistía, prescripción o circunstancias excluyentes de responsabilidad que impidan: «... prevenir, investigar, identificar y sancionar a los autores intelectuales y encubridores de violaciones de los derechos humanos» ${ }^{132}$, son inválidas a los efectos de la Convención y carecen de efectos jurídicos ${ }^{133}$, por obstaculizar la investigación y el acceso a un recurso judicial efectivo de los damnificados generando responsabilidad internacional del Estado por denegación de justicia ${ }^{134}$.

Este tipo de disposiciones internas encuentran su obstáculo en el artículo 27 de la Convención de Viena sobre Derecho de los Tratados ${ }^{135}$ y fuera de este ámbito convencional en el principio del derecho internacional del pacta sunt servanda $a^{136}$.

De esta manera, ha considerado la Corte IDH que: «... son inadmisibles las disposiciones de amnistía, las disposiciones de prescripción y el establecimiento de excluyentes de responsabilidad que pretendan impedir la investigación y sanción de los responsables de las violaciones graves de los derechos humanos tales como la tortura, las ejecuciones sumarias, extralegales o arbitrarias y las desapariciones forzadas, todas ellas prohibidas por contravenir derechos inderogables reconocidos por el Derecho Internacional de los Derechos Humanos» ${ }^{137}$.

132 Caso Loayza Tamayo Vs. Perú. Fondo. Sentencia de 17 de septiembre de 1997. Serie C N. 33, párr. 168.

133 Barrios Altos, op. cit., párr. 44.

134 Ibíd., párr. 43, donde destacamos: «La Corte estima necesario enfatizar que, a la luz de las obligaciones generales consagradas en los artículos 1.1 y 2 de la Convención Americana, los Estados Partes tienen el deber de tomar las providencias de toda índole para que nadie sea sustraído de la protección judicial y del ejercicio del derecho a un recurso sencillo y eficaz, en los términos de los artículos 8 y 25 de la Convención. Es por ello que los Estados Partes en la Convención que adopten leyes que tengan este efecto, como lo son las leyes de autoamnistía, incurren en una violación de los artículos 8 y 25 en concordancia con los artículos 1.1 y 2 de la Convención. Las leyes de autoamnistía conducen a la indefensión de las víctimas y a la perpetuación de la impunidad, por lo que son manifiestamente incompatibles con la letra y el espíritu de la Convención Americana. Este tipo de leyes impide la identificación de los individuos responsables de violaciones a derechos humanos, ya que se obstaculiza la investigación y el acceso a la justicia e impide a las víctimas y a sus familiares conocer la verdad y recibir la reparación correspondiente».

135 Si se desea ampliar el estudio de la relación entre la Convención de Viena Sobre Derecho de los Tratados y la jurisprudencia de la Corte IDH, puede consultarse: Córdoba Z., Francisco. La carta de derechos y la jurisprudencia de la Corte Interamericana, Bogotá, Editorial Temis S. A., 1994, págs. 46 y ss., donde también se verán referenciadas y explicadas las Opiniones Consultivas en relación al tema, en especial la OC-3/83, OC-4/84 y OC-5/85.

136 Bulacio, op. cit., párr. 117. Juan Humberto Sánchez, op. cit., párr. 60. Hermanos Gómez Paquiyauri, op. cit., párr. 151.

137 Bulacio, op. cit., párr. 41. También: Trujillo Oroza, op. cit., párr. 10. Myrna Mack Chang, op. cit., párr. 276. Molina Theissen, op. cit., párr. 83. 19 Comerciantes, op. cit., párr. 262. Tibi, op. cit., párr. 259. Masacre Plan de Sánchez, op. cit., párr. 99. Carpio Nicolle, op. cit., párr. 130. Hermanas Serrano Cruz, op. cit., párr. 172. Huilca Tecse, op. cit., párr. 108. Gutiérrez Soler, op. cit., párr. 97. 
No debe pensarse que estos fallos en su conjunto intentan reparar acciones producidas por gobiernos que no ajustaban sus acciones a un Estado de Derecho o durante gobiernos de facto y la posterior inacción de las incipientes democracias de finales del siglo xx, así es un ejemplo de lo que afirmamos el caso Caracazo Vs. Venezuela ${ }^{138}$ o Bulacio Vs. Argentina ${ }^{139}$, ente otros ${ }^{140}$, donde el criterio general es que: «El Estado debe remover todos los obstáculos y mecanismos de hecho y derecho que mantienen la impunidad $\rangle^{141}$, su misión es de reparación a las víctimas y de que a futuro estos hechos no se repitan, instrumentando, entre otros elementos, recursos judiciales efectivos.

\subsubsection{Regla del previo agotamiento de recursos internos}

Un punto importante en el ejercicio del derecho de defensa por parte de los Estados es la alegación del no agotamiento de los recursos internos ${ }^{142}$, que en muchos casos terminan no siendo idóneos para la protección que se reclama.

El cumplimiento de la regla del agotamiento de los recursos internos permite al Estado resolver sus conflictos sin verse enfrentado a un proceso internacional y hace referencia a la naturaleza coadyuvante y complementaria de la jurisdicción establecida en el «Preámbulo» de la Convención ${ }^{143}$.

Sin embargo, el Estado no puede alegar el agotamiento de los recursos internos, si no ha cumplido con el derecho de acceso a un recurso judicial efectivo y de este incumplimiento se deriva la consecuente denegación de justicia.

Desde sus inicios la Corte IDH se ha ocupado de la interrelación del recurso judicial efectivo y su concordancia con el resto de las normas que venimos comentando. En especial sobre el requisito de agotamiento de los recursos internos y su alegación como excepción previa de parte de los Estados. En este sentido ha

Gómez Palomino, op. cit., párr. 140. Blanco Romero, op. cit., párr. 98. Baldeón García, op. cit., párr. 201. Masacres de Ituango, op. cit., párr. 402. Montero Aranguren, op. cit., párr. 141.

138 Caracazo, op. cit.

139 Bulacio, op. cit., párr. 116.

140 A modo de ejemplos: Juan Humberto Sánchez, op. cit., párr. 60. Huilca Tecse, op. cit., párr. 108.

141 Myrna Mack Chang, op. cit., párr. 277.

142 Recordamos que establece la Convención en el artículo 46: «2. Las disposiciones de los incisos 1.a. y 1.b. del presente artículo no se aplicarán cuando: a) no exista en la legislación interna del Estado de que se trata el debido proceso legal para la protección del derecho o derechos que se alega han sido violados; b) no se haya permitido al presunto lesionado en sus derechos el acceso a los recursos de la jurisdicción interna, o haya sido impedido de agotarlos, y c) haya retardo injustificado en la decisión sobre los mencionados recursos».

143 Velásquez Rodríguez, op. cit., párrs. 61-62. En idéntico sentido: Godínez Cruz, op. cit., párrs. 64-65. Fairén Garbi y Solís Corrales, op. cit., párrs. 85-86. Caso Gangaram Panday Vs. Surinam. Excepciones Preliminares. Sentencia de 4 de diciembre de 1991. Serie C N. ${ }^{\circ} 12$, párr. 37. 
dicho el alto tribunal que: «... debe tenerse también en cuenta que la fundamentación de la protección internacional de los derechos humanos radica en la necesidad de salvaguardar a la víctima del ejercicio arbitrario del poder público... La inexistencia de recursos internos efectivos coloca a la víctima en estado de indefensión y explica la protección internacional. Por ello, cuando quien denuncia una violación de los derechos humanos aduce que no existen dichos recursos o que son ilusorios, la puesta en marcha de tal protección puede no sólo estar justificada sino ser urgente. En esos casos no solamente es aplicable el artículo 37.3 del Reglamento de la Comisión, a propósito de la carga de la prueba, sino que la oportunidad para decidir sobre los recursos internos debe adecuarse a los fines del régimen de protección internacional. De ninguna manera la regla del previo agotamiento debe conducir a que se detenga o se demore hasta la inutilidad la actuación internacional en auxilio de la víctima indefensa. Esa es la razón por la cual el artículo 46.2 establece excepciones a la exigibilidad de la utilización de los recursos internos como requisito para invocar la protección internacional, precisamente en situaciones en las cuales, por diversas razones, dichos recursos no son efectivos. Naturalmente cuando el Estado opone, en tiempo oportuno, esta excepción, la misma debe ser considerada y resuelta, pero la relación entre la apreciación sobre la aplicabilidad de la regla y la necesidad de una acción internacional oportuna en ausencia de recursos internos efectivos, puede aconsejar frecuentemente la consideración de las cuestiones relativas a aquella regla junto con el fondo de la materia planteada, para evitar que el trámite de una excepción preliminar demore innecesariamente el proceso» ${ }^{144}$.

También creemos muy ilustrativo el siguiente párrafo del caso Velásquez Rodríguez Vs. Honduras, donde se describen las consecuencias de lo que venimos diciendo: «La regla del previo agotamiento de los recursos internos en la esfera del derecho internacional de los derechos humanos, tiene ciertas implicaciones que están presentes en la Convención. En efecto, según ella, los Estados Partes se obligan a suministrar recursos judiciales efectivos a las víctimas de violación de los derechos humanos (artículo 25), recursos que deben ser sustanciados de conformidad con las reglas del debido proceso legal (artículo 8.1), todo ello dentro de la obligación general a cargo de los mismos Estados, de garantizar el libre y pleno ejercicio de los derechos reconocidos por la Convención a toda persona que se encuentre bajo su jurisdicción (artículo 1). Por eso, cuando se invocan ciertas excepciones a la regla de no agotamiento de los recursos internos, como son la inefectividad de tales recursos o la inexistencia del debido proceso legal, no sólo se

144 Caso Velásquez Rodríguez Vs. Honduras. Excepciones Preliminares. Sentencia de 26 de junio de 1987. Serie C N. ${ }^{\circ}$ 1, párr. 93. Fairén Garbi y Solís Corrales, op. cit., párr. 93. Godínez Cruz, op. cit., párr. 95. 
está alegando que el agraviado no está obligado a interponer tales recursos, sino que indirectamente se está imputando al Estado involucrado una nueva violación a las obligaciones contraídas por la Convención. En tales circunstancias la cuestión de los recursos internos se aproxima sensiblemente a la materia de fondo» ${ }^{145}$.

La alegación de la falta de agotamiento de los recursos internos, posee una determinada oportunidad procesal y ella está destinada a favor del Estado, por ello se ha dicho en el caso Fairén Garbi y Solís Corrales Vs. Honduras, donde se obstaculizaba el acceso a los recursos de hábeas corpus en la jurisdicción interna en casos de desapariciones forzadas y los recursos similares intentados se habían demorado injustificadamente, que: «Dadas las especiales circunstancias de este caso, no es necesario determinar si se cumplieron trámites dirigidos a agotar los recursos de la jurisdicción hondureña. En efecto, para resolver el punto planteado la Corte observa, en primer lugar, que el Gobierno no hizo valer la excepción de los recursos internos en el momento en que recibió la comunicación formal de la petición introducida ante la Comisión, como medio para oponerse a la admisibilidad de la misma, y tampoco respondió a la solicitud de información de la Comisión. Este hecho, en sí mismo, bastaría para rechazar la excepción, pues la regla del previo agotamiento es un requisito establecido en provecho del Estado, el cual puede renunciar a hacerlo valer, aun de modo tácito, lo que ocurre inter alia cuando no se interpone oportunamente para fundamentar la inadmisibilidad de una denuncia» ${ }^{146}$.

A su vez en el mismo caso se ha establecido que ${ }^{147}$ : 1) El agotamiento de los recursos internos es norma de derecho internacional. 2) No se aplica en caso de no haber recursos que agotar.

Posteriormente los parámetros para su alegación han sido concretados del siguiente modo $^{148}:$ 1) Puede ser renunciada en forma expresa o tácita por el Estado

145 Velásquez Rodríguez, op. cit., párr. 91. En idéntica forma: caso Fairén Garbi y Solís Corrales Vs. Honduras. Excepciones Preliminares. Sentencia de 26 de junio de 1987. Serie C N. . 2, párr. 90. Godínez Cruz, op. cit., párr. 93. Y muy recientemente: Castañeda Gutman, op. cit., párrs. 34-36.

146 Fairén Garbi y Solís Corrales, op. cit., párrs. 108-109. En el mismo sentido y entre otros: Comunidad Indígena Sawhoyamaxa, op. cit., párrs. 99-101.

147 Ibíd., 110. Y entre otros: Niñas Yean y Bosico, op. cit., párr. 63.

148 Gangaram Panday, op. cit., párr. 38. Que a su vez en la serie A cuenta con el antecedente del caso: Asunto de Viviana Gallardo y otras, Decisión del 13 de noviembre de 1981, N. ${ }^{\circ}$ G 101/81. Serie A, párr. 26. Caso Neira Alegría y otros Vs. Perú. Excepciones Preliminares. Sentencia de 11 de diciembre de 1991. Serie C N. ${ }^{\circ}$ 13, párr. 30. Caso de la Comunidad Mayagna (Sumo) Awas Tingni Vs. Nicaragua. Excepciones Preliminares. Sentencia de 1 de febrero de 2000. Serie C N. ${ }^{\circ}$ 66, párrs. 53-59. Caso Herrera Ulloa Vs. Costa Rica. Excepciones Preliminares, Fondo, Reparaciones y Costas. Sentencia de 2 de julio de 2004. Serie C N.o 107, párrs. 79-87. Tibi, op. cit., párrs. 4755. Hermanas Serrano Cruz, op. cit., párrs. 132-142. Comunidad Moiwana, op. cit., párrs. 48-51. Niñas Yean y Bosico, op. cit., párrs. 59-65. García Asto y Ramírez Rojas, op. cit., párrs. 48-50. Acevedo Jaramillo, op. cit., párrs 121-127. Almonacid Arellano, op. cit., párrs. 64-65. 
que tiene derecho a invocarla. 2) Para ser oportuna, debe plantearse en las primeras etapas del procedimiento ante la Comisión, probando la idoneidad de los recursos ${ }^{149}$ y a falta de esto podrá presumirse la renuncia tácita a valerse de la misma por parte del Estado interesado ${ }^{150}$. 3) El Estado que alega el no agotamiento tiene a su cargo el señalamiento de los recursos internos que deben agotarse y de su efectividad. 4) La eficacia de su alegación está sujeta al principio del Estoppel o de los actos propios $^{151}$.5) La interposición de la excepción debe ser realizada de manera expresa y clara, bajo pena de considerarse renuncia tácita ${ }^{152}$.6) El retardo injustificado en tomarse la decisión imposibilita su alegación y se constituye como excepción a la regla del agotamiento de los recursos internos ${ }^{153}$.7) El recurso extraordinario o de

149 Se ha tomado la renuncia tácita por falta de prueba de la idoneidad en: Niñas Yean y Bosico, op. cit., párr. 64.

150 Castillo Petruzzi, op. cit., párr. 56 y toda la jurisprudencia europea allí citada. Tibi, op. cit., párr. 52. Comunidad Moiwana, op. cit., párr. 50. Acevedo Jaramillo, op. cit., párr. 126.

151 Neira Alegría, op. cit., párr. 29. En particular destacamos: «De lo expuesto surge, pues, que el Perú sostuvo el 29 de septiembre de 1989 que las instancias internas no se habían agotado en tanto que, un año después, 24 de septiembre de 1990, ante la Comisión y ahora, ante la Corte, afirma lo contrario. Según la práctica internacional cuando una parte en un litigio ha adoptado una actitud determinada que redunda en beneficio propio o en deterioro de la contraria, no puede luego, en virtud del principio del Estoppel, asumir otra conducta que sea contradictoria con la primera. Para la segunda actitud rige la regla de non concedit venire contra factum proprium. Se podría argumentar en este caso que el trámite ante el Fuero Privativo Militar no constituye verdaderamente un recurso o que ese Fuero no forma parte de los tribunales judiciales. Ninguna de estas afirmaciones sería aquí relevante. Lo que importa, por el contrario, es que el Gobierno ha sostenido, en cuanto al agotamiento de los recursos, dos afirmaciones contradictorias acerca de su derecho interno e independientemente de la veracidad de cada una de ellas, esa contradicción afecta la situación procesal de la parte contraria». En el mismo sentido: caso Durand y Ugarte Vs. Perú. Excepciones Preliminares. Sentencia de 28 de mayo de 1999. Serie C N. ${ }^{\circ}$ 50, párr. 38. Almonacid Arellano, op. cit., párr. 65.

152 Caso Castillo Páez Vs. Perú. Excepciones Preliminares. Sentencia de 30 de enero de 1996. Serie C N. . 24, párr. 42, donde se dijo: «Si bien es verdad, que en los escritos presentados por el Gobierno ante la Comisión durante la tramitación del asunto se señalaron, entre otros datos, el desarrollo de los procesos de hábeas corpus y el de naturaleza penal relacionados con la desaparición del señor Ernesto Rafael Castillo Páez, sin embargo, éste no opuso de manera clara en las primeras etapas del procedimiento ante la Comisión la excepción de no agotamiento de los recursos internos, pues sólo fue invocado de manera expresa tal hecho, en el informe preparado por el equipo de trabajo presentado por el Gobierno ante la Comisión el 3 de enero de 1995, en respuesta al Informe 19/94 aprobado por la misma Comisión el 26 de septiembre de 1994, que sirvió de apoyo a la demanda ante esta Corte». Y ante esto se consideró una renuncia tácita por parte del Estado a la interposición. En el mismo sentido: caso Loayza Tamayo Vs. Perú. Excepciones Preliminares. Sentencia de 31 de enero de 1996. Serie C N.o 25, párrs. 42-43.

153 Genie Lacayo, op. cit., párrs. 56 y 80-81. Caso Las Palmeras Vs. Colombia. Excepciones Preliminares. Sentencia de 4 de febrero de 2000. Serie C N. ${ }^{\circ}$ 67, párrs. 37-39. Juan Humberto Sánchez, op. cit., párrs. 64-69, aquí la Corte IDH ha dado las razones procesales y de fondo sobre este tema, pasemos a ver, citando al párr. 67: «Esta Corte considera que en el caso sub júdice se ha dado un retardo injustificado en la decisión sobre los mencionados recursos inter- 
inconstitucionalidad u otro análogo como podría ser el de inaplicabilidad de la ley, que se encuentre en vías de resolución, no necesariamente implica el otorgamiento de la excepción a favor del Estado, de este modo se ha dicho que: «La Corte considera pertinente señalar que "la acción de inconstitucionalidad" es de carácter extraordinario, y tiene por objeto el cuestionamiento de una norma y no la revisión de un fallo. De esta manera, dicha acción no puede ser considerada como un recurso interno que deba necesariamente ser siempre agotada por el peticionario» ${ }^{154}$.

\section{Conclusiones}

Como balance de lo desarrollado podemos decir que:

No se han encontrado contradicciones en las sentencias de la Corte IDH en esta temática, sino progresividad jurisprudencial, acorde con los hechos planteados en los diferentes casos a través del tiempo.

El derecho a un recurso judicial efectivo posee el rango de principio y de costumbre del derecho internacional.

El sentido de «pilan» que se le otorga al artículo 25 contribuye decisivamente a asegurar la justicia. El derecho a un recurso judicial efectivo posee una estrecha relación con las obligaciones generales consagradas en la Convención, constituyéndose como un derecho autónomo. En este sentido, si bien posee una relación directa con el artículo 8.1, en su autonomía permanece como independiente de éste y no necesariamente la infracción de un derecho conlleva la del otro.

En su relación con el derecho de acceso la justicia, el artículo 25 se constituye como uno de sus cimientos, pero no es el único, emanando también el derecho enunciado de los artículos 1.1, 2 y 8 de la Convención.

El Estado debe brindar las condiciones para que el recurso pueda ser desarrollado, donde se incluye, la debida fundamentación de la sentencia. Así, su ámbito de

nos, ya que si bien se iniciaron las investigaciones en sede penal en octubre de 1992 a la fecha no se ha sancionado a los responsables materiales e intelectuales de la ejecución extrajudicial del señor Juan Humberto Sánchez. El retardo injustificado es una reconocida excepción al previo agotamiento de los recursos internos. Como lo ha indicado la Corte, en la jurisdicción internacional lo esencial es que se preserven las condiciones necesarias para que los derechos procesales de las partes no sean disminuidos o desequilibrados, y para que se alcancen los fines para los cuales han sido diseñados los distintos procedimientos. En el presente caso, por haberse configurado un retardo injustificado en los recursos internos, no se aplica el requisito de su previo agotamiento como condición de admisibilidad de la petición». En igual sentido ver: Hermanas Serrano Cruz, op. cit., párrs. 138-139. Acevedo Jaramillo, op. cit., párr. 127.

${ }^{154}$ Herrera Ulloa, op. cit., párr. 85. 
aplicación es el de garantizar que los Estados, como deber positivo, otorguen recursos efectivos para la salvaguarda de los derechos, centrados por una parte en el amparo de los derechos fundamentales, pero que a su vez no se circunscribe solamente a ello, sino que abarca todo derecho fundamental reconocido en la Convención, la Constitución o la ley.

Se configura como un derecho no absoluto, cuyo límite es la no denegación de justicia y en ningún caso las limitaciones pueden llevar a contravenir obligaciones internacionales.

La ausencia de celeridad e inmediatez en la resolución de una medida de amparo interpuesta hace a la violación del artículo 25.1 del Pacto.

El cumplimiento de la regla del agotamiento de los recursos internos, permite al Estado resolver sus conflictos sin verse enfrentado a un proceso internacional y hace referencia a la naturaleza coadyuvante y complementaria de la jurisdicción establecida en el «Preámbulo» de la Convención, sin embargo, el Estado no puede alegar el agotamiento de los recursos internos si no ha cumplido con el derecho de acceso a un recurso judicial efectivo y de este incumplimiento se deriva la consecuente denegación de justicia. 


\section{Referências}

\subsection{Autores}

Acosta Alvarado, Paola Andrea. El derecho de acceso a la justicia en la jurisprudencia interamericana, Bogotá, Universidad Externado de Colombia, 2007.

Alto Comisionado de las Naciones Unidas para los Derechos Humanos - Oficina de Colombia. Interpretación de las normas internacionales sobre derechos humanos, Bogotá, 2002.

Alto Comisionado de las Naciones Unidas para los Derechos Humanos. Recomendaciones de órganos internacionales de derechos humanos al Estado colombiano.

Arias Ávila, Néstor Oswaldo. El tratamiento internacional de la suspensión de garantías judiciales en los estados de excepción, Bogotá, Escuela Superior de Administración Pública, 1993.

Barberis, Julio A. Formación del derecho internacional, Buenos Aires, Ábaco de Rodolfo Depalma, 1994. Brague Camazano, Joaquín. Los límites a los derechos fundamentales, Madrid, Dykinson S. L., 2004.

Cianciardo, Juan. El conflictivismo en los derechos fundamentales, 2. ${ }^{a}$ ed. actualizada y ampliada, Pamplona, Eunsa, 2000.

Cianciardo, Juan. El ejercicio regular de los derechos. Análisis y crítica del conflictivismo, Buenos Aires, Ad-Hoc, 2007.

Ciuro Caldani, Miguel Ángel. Estudios de filosofía del derecho internacional privado, Rosario, Fundación para las Investigaciones Jurídicas, 1997.

Córdoba Z., Francisco. La carta de derechos y la jurisprudencia de la Corte Interamericana, Bogotá, Editorial Temis S. A., 1994.

Feuillade, Milton C. Cooperación jurisdiccional internacional, Buenos Aires, Ábaco de Rodolfo Depalma, en prensa.

López Guerra, Luis. «Derechos fundamentales y estados de excepción», en Nieto NaviA, Rafael ed. La Corte y el Sistema Interamericano de Derechos Humanos, San José, Corte Interamericana de Derechos Humanos, 1994.

Medina Quiroga, Cecilia. La Convención Americana: teoría y jurisprudencia. Vida, integridad personal, libertad personal, debido proceso y recurso judicial, San José, Universidad de Chile, 2005.

O'Donelt, Daniel. Derecho internacional de los Derechos Humanos - Normativa, jurisprudencia y doctrina de los sistemas Universal e Interamericano, Bogotá, Alejandro Valencia Villa, 2004.

Serna, Pedro, Toller Fernando. La interpretación constitucional de los derechos fundamentales. Una alternativa a los conflictos de derechos, Buenos Aires, La Ley, 2000.

TolLer, Fernando. «Propuestas para un nuevo modelo de interpretación en la resolución de conflictos entre derechos constitucionales», en Anuario de Derecho de la Universidad Austral, n. ${ }^{\circ}$ 4, Buenos Aires, 1998. Virally, Michel. El devenir del derecho internacional, trad. Tipie Isoard, Eliane Cazenave, México, Fondo de Cultura Económica; 1998.

\subsection{Normas}

ONU. Convención de Viena sobre el Derecho de los Tratados. Doc. A/Conf.39/27 (1969), 1155 U.N.T.S. 331.

\subsection{Jurisprudencia de la Corte Interamericana de Derechos Humanos}

\subsubsection{Casos contenciosos}

Corte Interamericana de Derechos Humanos. Caso Velásquez Rodríguez Vs. Honduras. Excepciones Preliminares. Sentencia de 26 de junio de 1987. Serie C N. ${ }^{\circ} 1$.

Corte Interamericana de Derechos Humanos. Caso Fairén Garbi y Solís Corrales Vs. Honduras. Excepciones Preliminares. Sentencia de 26 de junio de 1987. Serie C N. ${ }^{\circ} 2$. 
Corte Interamericana de Derechos Humanos. Caso Godínez Cruz Vs. Honduras. Excepciones Preliminares. Sentencia de 26 de junio de 1987 . Serie C N. 3.

Corte Interamericana de Derechos Humanos. Caso Velásquez Rodríguez Vs. Honduras. Fondo. Sentencia del 29 de julio de 1988. Serie C N. ${ }^{\circ} 4$.

Corte Interamericana de Derechos Humanos. Caso Godínez Cruz Vs. Honduras. Fondo. Sentencia del 20 de enero de 1989. Serie C N. ${ }^{\circ} 5$.

Corte Interamericana de Derechos Humanos. Caso Fairén Garbi y Solís Corrales Vs. Honduras. Fondo. Sentencia del 15 de marzo de 1989. Serie C N. ${ }^{\circ} 6$.

Corte Interamericana de Derechos Humanos. Caso Gangaram Panday Vs. Surinam. Excepciones Preliminares. Sentencia de 4 de diciembre de 1991. Serie C N. ${ }^{\circ} 12$.

Corte Interamericana de Derechos Humanos. Caso Neira Alegría y otros Vs. Perú. Excepciones Preliminares. Sentencia de 11 de diciembre de 1991. Serie C N. ${ }^{\circ} 13$.

Corte Interamericana de Derechos Humanos. Caso Caballero Delgado y Santana Vs. Colombia. Excepciones Preliminares. Sentencia del 21 de enero de1994. Serie C N. 17.

Corte Interamericana de Derechos Humanos. Caso Castillo Páez Vs. Perú. Excepciones Preliminares. Sentencia de 30 de enero de 1996. Serie C N. ${ }^{\circ} 24$.

Corte Interamericana de Derechos Humanos. Caso El Amparo Vs. Venezuela. Reparaciones y Costas. Sentencia de 14 de septiembre de 1996. Serie C N. ${ }^{\circ} 28$.

Corte Interamericana de Derechos Humanos. Caso Genie Lacayo Vs. Nicaragua. Fondo, Reparaciones y Costas. Sentencia de 29 de enero de 1997. Serie C N. ${ }^{\circ} 30$.

Corte Interamericana de Derechos Humanos. Caso Loayza Tamayo Vs. Perú. Fondo. Sentencia de 17 de septiembre de 1997. Serie C N. 33.

Corte Interamericana de Derechos Humanos. Caso Castillo Páez Vs. Perú. Fondo. Sentencia de 3 de noviembre de 1997. Serie C N. 34.

Corte Interamericana de Derechos Humanos. Caso Suárez Rosero Vs. Ecuador. Fondo. Sentencia de 12 de noviembre de 1997. Serie C N. ${ }^{o} 35$.

Corte Interamericana de Derechos Humanos. Caso Blake Vs. Guatemala. Fondo. Sentencia de 24 de enero de 1998. Serie C N. 36.

Corte Interamericana de Derechos Humanos. Caso de la «Panel Blanca» (Paniagua Morales y otros) Vs. Guatemala. Fondo. Sentencia de 8 de marzo de 1998. Serie C N. 37.

Corte Interamericana de Derechos Humanos. Caso Garrido y Baigorria Vs. Argentina. Reparaciones y Costas. Sentencia de 27 de agosto de 1998. Serie C N. 39.

Corte Interamericana de Derechos Humanos. Caso Castillo Petruzzi y otros Vs. Perú. Excepciones Preliminares. Sentencia de 4 de septiembre de 1998. Serie C N. 41.

Corte Interamericana de Derechos Humanos. Caso Loayza Tamayo Vs. Perú. Reparaciones y Costas. Sentencia de 27 de noviembre de 1998. Serie C N. ${ }^{\circ} 42$.

Corte Interamericana de Derechos Humanos. Caso Castillo Páez Vs. Perú. Reparaciones y Costas. Sentencia de 27 de noviembre de 1998. Serie C N. ${ }^{\circ} 43$.

Corte Interamericana de Derechos Humanos. Caso Suárez Rosero Vs. Ecuador. Reparaciones y Costas. Sentencia de 20 de enero de 1999 . Serie C N. ${ }^{\circ} 44$.

Corte Interamericana de Derechos Humanos. Caso Castillo Páez Vs. Perú. Reparaciones y Costas. Sentencia de 27 de noviembre de 1998. Serie C N. 48.

Corte Interamericana de Derechos Humanos. Caso Durand y Ugarte Vs. Perú. Excepciones Preliminares. Sentencia de 28 de mayo de 1999. Serie C N. 50.

Corte Interamericana de Derechos Humanos. Caso Castillo Petruzzi y otros Vs. Perú. Fondo, Reparaciones y Costas. Sentencia de 30 de mayo de 1999. Serie C N. ${ }^{\circ} 52$.

Corte Interamericana de Derechos Humanos. Caso Cesti Hurtado Vs. Perú. Fondo. Sentencia de 29 de septiembre de 1999. Serie C N. ${ }^{\circ} 56$.

Corte Interamericana de Derechos Humanos. Caso del Caracazo Vs. Venezuela. Fondo. Sentencia de 11 de noviembre de 1999. Serie C N. ${ }^{\circ} 58$.

Corte Interamericana de Derechos Humanos. Caso de los «Niños de la Calle» (Villagrán Morales y otros) Vs. Guatemala. Fondo. Sentencia de 19 de noviembre de 1999. Serie C N. 63. 
Corte Interamericana de Derechos Humanos. Caso Trujillo Oroza Vs. Bolivia. Fondo. Sentencia de 26 de enero de 2000. Serie C N. ${ }^{\circ} 64$.

Corte Interamericana de Derechos Humanos. Caso de la Comunidad Mayagna (Sumo) Awas Tingni Vs. Nicaragua. Excepciones Preliminares. Sentencia de 1 de febrero de 2000. Serie C N. 66.

Corte Interamericana de Derechos Humanos. Caso Las Palmeras Vs. Colombia. Excepciones Preliminares. Sentencia de 4 de febrero de 2000 . Serie C N. ${ }^{\circ} 67$.

Corte Interamericana de Derechos Humanos. Caso Durand y Ugarte Vs. Perú. Fondo. Sentencia de 16 de agosto de 2000. Serie C N. ${ }^{\circ} 68$.

Corte Interamericana de Derechos Humanos. Caso Cantoral Benavides Vs. Perú. Fondo. Sentencia de 18 de agosto de 2000. Serie C N. ${ }^{\circ} 69$.

Corte Interamericana de Derechos Humanos. Caso Bámaca Velásquez Vs. Guatemala. Fondo. Sentencia de 25 de noviembre de 2000 . Serie C N. ${ }^{\circ} 70$.

Corte Interamericana de Derechos Humanos. Caso del Tribunal Constitucional Vs. Perú. Fondo, Reparaciones y Costas. Sentencia de 31 de enero de 2001. Serie C N. 71.

Corte Interamericana de Derechos Humanos. Caso Baena Ricardo y otros Vs. Panamá. Fondo, Reparaciones y Costas. Sentencia de 2 de febrero de 2001. Serie C N. ${ }^{\circ} 72$.

Corte Interamericana de Derechos Humanos. Caso «La Última Tentación de Cristo» (Olmedo Bustos y otros). Sentencia de 5 de febrero de 2001. Serie C N. ${ }^{\circ} 73$.

Corte Interamericana de Derechos Humanos. Caso Ivcher Bronstein Vs. Perú. Reparaciones y Costas. Sentencia de 6 de febrero de 2001. Serie C N. ${ }^{\circ} 74$.

Corte Interamericana de Derechos Humanos. Caso Barrios Altos Vs. Perú. Fondo. Sentencia de 14 de marzo de 2001. Serie C N. ${ }^{\circ} 75$.

Corte Interamericana de Derechos Humanos. Caso de la «Panel Blanca» (Paniagua Morales y otros) Vs. Guatemala. Reparaciones y Costas. Sentencia de 25 de mayo de 2001. Serie C N. ${ }^{\circ} 76$.

Corte Interamericana de Derechos Humanos. Caso de los «Niños de la Calle» (Villagrán Morales y otros) Vs. Guatemala. Reparaciones y Costas. Sentencia de 26 de mayo de 2001. Serie C N. 77.

Corte Interamericana de Derechos Humanos. Caso Cesti Hurtado Vs. Perú. Reparaciones y Costas. Sentencia de 31 de mayo de 2001. Serie C N. ${ }^{\circ} 78$.

Corte Interamericana de Derechos Humanos. Caso de la Comunidad Mayagna (Sumo) Awas Tingni Vs. Nicaragua. Fondo, Reparaciones y Costas. Sentencia de 31 de agosto de 2001. Serie C N. 79.

Corte Interamericana de Derechos Humanos. Caso Barrios Altos Vs. Perú. Interpretación de la Sentencia de Fondo. Sentencia de 3 de septiembre de 2001. Serie C N. ${ }^{\circ} 83$.

Corte Interamericana de Derechos Humanos. Caso Cantoral Benavides Vs. Perú. Reparaciones y Costas. Sentencia de 3 de diciembre de 2001. Serie C N. ${ }^{\circ} 88$.

Corte Interamericana de Derechos Humanos. Caso Las Palmeras Vs. Colombia. Fondo. Sentencia de 6 de diciembre de 2001. Serie C N. ${ }^{\circ} 90$.

Corte Interamericana de Derechos Humanos. Caso Bámaca Velásquez Vs. Guatemala. Reparaciones y Costas. Sentencia de 22 de febrero de 2002. Serie C N. ${ }^{\circ} 91$.

Corte Interamericana de Derechos Humanos. Caso Trujillo Oroza Vs. Bolivia. Reparaciones y Costas. Sentencia de 27 de febrero de 2002. Serie C N. ${ }^{\circ} 92$.

Corte Interamericana de Derechos Humanos. Caso Hilaire, Constantine y Benjamin y otros Vs. Trinidad y Tobago. Fondo, Reparaciones y Costas. Sentencia de 21 de junio de 2002. Serie C N. ${ }^{\circ} 94$.

Corte Interamericana de Derechos Humanos. Caso Del Caracazo Vs. Venezuela. Reparaciones y Costas. Sentencia de 29 de agosto de 2002. Serie C N. 95.

Corte Interamericana de Derechos Humanos. Caso Las Palmeras Vs. Colombia. Reparaciones y Costas. Sentencia de 26 noviembre de 2002. Serie C N. ${ }^{\circ} 96$.

Corte Interamericana de Derechos Humanos. Caso Cantos Vs. Argentina. Fondo, Reparaciones y Costas. Sentencia de 28 de noviembre de 2002. Serie C N. ${ }^{\circ} 97$.

Corte Interamericana de Derechos Humanos. Caso «Cinco Pensionistas» Vs. Perú. Fondo, Reparaciones y Costas. Sentencia de 28 de febrero de 2003. Serie C N. ${ }^{\circ} 98$.

Corte Interamericana de Derechos Humanos. Caso Juan Humberto Sánchez Vs. Honduras. Excepción Preliminar, Fondo, Reparaciones y Costas. Sentencia de 7 de junio de 2003. Serie C N. 99. 
Corte Interamericana de Derechos Humanos. Caso Bulacio Vs. Argentina. Fondo, Reparaciones y Costas. Sentencia de 18 de septiembre de 2003. Serie C N. ${ }^{\circ} 100$.

Corte Interamericana de Derechos Humanos. Caso Myrna Mack Chang Vs. Guatemala. Fondo, Reparaciones y Costas. Sentencia de 25 de noviembre de 2003. Serie C N. ${ }^{\circ} 101$.

Corte Interamericana de Derechos Humanos. Caso Juan Humberto Sánchez Vs. Honduras. Interpretación de la Sentencia de Excepción Preliminar, Fondo y Reparaciones. Sentencia de 26 de noviembre de 2003. Serie C N. ${ }^{\circ} 102$.

Corte Interamericana de Derechos Humanos. Caso Maritza Urrutia Vs. Guatemala. Fondo, Reparaciones y Costas. Sentencia de 27 de noviembre de 2003. Serie C N. ${ }^{\circ} 103$.

Corte Interamericana de Derechos Humanos. Caso Baena Ricardo y otros Vs. Panamá. Competencia. Sentencia de 28 de noviembre de 2003. Serie C N. ${ }^{\circ} 104$.

Corte Interamericana de Derechos Humanos. Caso Herrera Ulloa Vs. Costa Rica. Excepciones Preliminares, Fondo, Reparaciones y Costas. Sentencia de 2 de julio de 2004. Serie C N. 107.

Corte Interamericana de Derechos Humanos. Caso Molina Theissen Vs. Guatemala. Reparaciones y Costas. Sentencia de 3 de julio de 2004. Serie C N. ${ }^{\circ} 108$.

Corte Interamericana de Derechos Humanos. Caso 19 Comerciantes Vs. Colombia. Fondo, Reparaciones y Costas. Sentencia de 5 de julio de 2004. Serie C N. ${ }^{\circ} 109$.

Corte Interamericana de Derechos Humanos. Caso de los Hermanos Gómez Paquiyauri Vs. Perú. Fondo, Reparaciones y Costas. Sentencia de 8 de julio de 2004. Serie C N. ${ }^{\circ} 110$.

Corte Interamericana de Derechos Humanos. Caso Ricardo Canese Vs. Paraguay. Fondo, Reparaciones y Costas. Sentencia de 31 de agosto de 2004. Serie C N. ${ }^{\circ} 111$.

Corte Interamericana de Derechos Humanos. Caso «Instituto de Reeducación del Menon» Vs. Paraguay. Excepciones Preliminares, Fondo, Reparaciones y Costas. Sentencia de 2 de septiembre de 2004. Serie C N. ${ }^{\circ} 112$. Corte Interamericana de Derechos Humanos. Caso Tibi Vs. Ecuador. Excepciones Preliminares, Fondo, Reparaciones y Costas. Sentencia de 7 de septiembre de 2004. Serie C N. ${ }^{o} 114$.

Corte Interamericana de Derechos Humanos. Caso Masacre Plan de Sánchez Vs. Guatemala. Reparaciones y Costas. Sentencia de 19 de noviembre 2004. Serie C N. 116.

Corte Interamericana de Derechos Humanos. Caso Carpio Nicolle y otros Vs. Guatemala. Fondo, Reparaciones y Costas. Sentencia de 22 de noviembre 2004. Serie C N. 117.

Corte Interamericana de Derechos Humanos. Caso de las Hermanas Serrano Cruz Vs. El Salvador. Excepciones Preliminares. Sentencia del 23 de noviembre de 2004. Serie C N. ${ }^{\circ} 118$.

Corte Interamericana de Derechos Humanos. Caso de las Hermanas Serrano Cruz Vs. El Salvador. Fondo, Reparaciones y Costas. Sentencia de 01 de marzo de 2005. Serie C N. ${ }^{\circ} 120$.

Corte Interamericana de Derechos Humanos. Caso Huilca Tecse Vs. Perú. Fondo, Reparaciones y Costas. Sentencia de 03 de marzo de 2005. Serie C N. ${ }^{\circ} 121$.

Corte Interamericana de Derechos Humanos. Caso Caesar Vs. Trinidad y Tobago. Fondo, Reparaciones y Costas. Sentencia 11 de marzo 2005. Serie C N. 123.

Corte Interamericana de Derechos Humanos. Caso de la Comunidad Moiwana Vs. Surinam. Excepciones Preliminares, Fondo, Reparaciones y Costas. Sentencia 15 de junio de 2005. Serie C N. ${ }^{\circ} 124$.

Corte Interamericana de Derechos Humanos. Caso Comunidad Indígena Yakye Axa Vs. Paraguay. Fondo Reparaciones y Costas. Sentencia 17 de junio de 2005. Serie C N. ${ }^{\circ} 125$.

Corte Interamericana de Derechos Humanos. Caso Yatama Vs. Nicaragua. Excepciones Preliminares, Fondo, Reparaciones y Costas. Sentencia de 23 de junio de 2005. Serie C N. 127.

Corte Interamericana de Derechos Humanos. Caso Acosta Calderón Vs. Ecuador. Fondo, Reparaciones y Costas. Sentencia de 24 de junio de 2005. Serie C N. ${ }^{\circ} 129$.

Corte Interamericana de Derechos Humanos. Caso de las Niñas Yean y Bosico Vs. República Dominicana. Excepciones Preliminares, Fondo, Reparaciones y Costas. Sentencia de 8 de septiembre de 2005. Serie C N. ${ }^{\circ} 130$. Corte Interamericana de Derechos Humanos. Caso Gutiérrez Soler Vs. Colombia. Fondo, Reparaciones y Costas. Sentencia de 12 de septiembre de 2005. Serie C N. ${ }^{\circ} 132$.

Corte Interamericana de Derechos Humanos. Caso de la Masacre de Mapiripán Vs. Colombia. Fondo, Reparaciones y Costas. Sentencia de 15 de septiembre de 2005. Serie C N. ${ }^{\circ} 134$.

Corte Interamericana de Derechos Humanos. Caso Palamara Iribarne Vs. Chile. Fondo, Reparaciones y 
Costas. Sentencia de 22 de noviembre de 2005. Serie C N. ${ }^{\circ} 135$.

Corte Interamericana de Derechos Humanos. Caso Gómez Palomino Vs. Perú. Fondo, Reparaciones y Costas. Sentencia de 22 de noviembre de 2005. Serie C N. ${ }^{\circ} 136$.

Corte Interamericana de Derechos Humanos. Caso García Asto y Ramírez Rojas Vs. Perú. Excepción Preliminar, Fondo, Reparaciones y Costas. Sentencia de 25 de noviembre de 2005. Serie C N. ${ }^{\circ} 137$.

Corte Interamericana de Derechos Humanos. Caso Blanco Romero y otros Vs. Venezuela. Fondo, Reparaciones y Costas. Sentencia de 28 de noviembre de 2005. Serie C N. ${ }^{0} 138$.

Corte Interamericana de Derechos Humanos. Caso Ximenes Lopes Vs. Brasil. Excepción Preliminar. Sentencia de 30 de noviembre de 2005. Serie C N. ${ }^{\circ} 139$.

Corte Interamericana de Derechos Humanos. Caso de la Masacre de Pueblo Bello Vs. Colombia. Fondo, Reparaciones y Costas. Sentencia de 31 de enero de 2006. Serie C N. ${ }^{o} 140$.

Corte Interamericana de Derechos Humanos. Caso López Álvarez Vs. Honduras. Fondo, Reparaciones y Costas. Sentencia de 1 de febrero de 2006. Serie C N. ${ }^{\circ} 141$.

Corte Interamericana de Derechos Humanos. Caso Acevedo Jaramillo y otros Vs. Perú. Excepciones Preliminares. Fondo. Reparaciones y Costas. Sentencia del 7 de febrero de 2006. Serie C N.o 144.

Corte Interamericana de Derechos Humanos. Caso Comunidad Indígena Sawhoyamaxa Vs. Paraguay. Fondo, Reparaciones y Costas. Sentencia de 29 de marzo de 2006. Serie C N. ${ }^{o} 146$.

Corte Interamericana de Derechos Humanos. Caso Baldeón García Vs. Perú. Fondo, Reparaciones y Costas. Sentencia de 6 de abril de 2006. Serie C N. ${ }^{\circ} 147$.

Corte Interamericana de Derechos Humanos. Caso de las Masacres de Ituango Vs. Colombia. Excepción Preliminar, Fondo, Reparaciones y Costas. Sentencia de 1 de julio de 2006 Serie C N. ${ }^{\circ} 148$.

Corte Interamericana de Derechos Humanos. Caso Ximenes Lopes Vs. Brasil. Fondo, Reparaciones y Costas. Sentencia de 4 de julio de 2006. Serie C N. ${ }^{\circ} 149$.

Corte Interamericana de Derechos Humanos. Caso Montero Aranguren y otros (Retén de Catia) Vs. Venezuela. Excepción Preliminar, Fondo, Reparaciones y Costas. Sentencia de 5 de julio de 2006. Serie C N. 150.

Corte Interamericana de Derechos Humanos. Caso Claude Reyes y otros Vs. Chile. Fondo, Reparaciones y Costas. Sentencia de 19 de septiembre de 2006. Serie C N. ${ }^{\circ} 151$.

Corte Interamericana de Derechos Humanos. Caso Servellón García y otros Vs. Honduras. Fondo, Reparaciones y Costas. Sentencia de 21 de septiembre de 2006. Serie C N. ${ }^{\circ} 152$.

Corte Interamericana de Derechos Humanos. Caso Goiburú y otros Vs. Paraguay. Fondo, Reparaciones y Costas. Sentencia de 22 de septiembre de 2006. Serie C N. ${ }^{\circ} 153$.

Corte Interamericana de Derechos Humanos. Caso Almonacid Arellano y otros Vs. Chile. Excepciones Preliminares, Fondo, Reparaciones y Costas. Sentencia de 26 de septiembre de 2006. Serie C N. ${ }^{o} 154$.

Corte Interamericana de Derechos Humanos. Caso Vargas Areco Vs. Paraguay. Fondo, Reparaciones y Costas. Sentencia de 26 de septiembre de 2006. Serie C N. ${ }^{\circ} 155$.

Corte Interamericana de Derechos Humanos. Caso Trabajadores Cesados del Congreso (Aguado Alfaro y otros) Vs. Perú. Excepciones Preliminares, Fondo, Reparaciones y Costas. Sentencia de 24 de noviembre de 2006. Serie C N. ${ }^{\circ} 158$.

Corte Interamericana de Derechos Humanos. Caso del Penal Miguel Castro Castro Vs. Perú. Fondo, Reparaciones y Costas. Sentencia de 25 de noviembre de 2006. Serie C N. ${ }^{\circ} 160$.

Corte Interamericana de Derechos Humanos. Caso La Cantuta Vs. Perú. Fondo, Reparaciones y Costas. Sentencia de 29 de noviembre de 2006. Serie C N. ${ }^{\circ} 162$.

Corte Interamericana de Derechos Humanos. Caso de la Masacre de la Rochela Vs. Colombia. Fondo, Reparaciones y Costas. Sentencia de 11 de de mayo de 2007. Serie C N. 163.

Corte Interamericana de Derechos Humanos. Caso Bueno Alves Vs. Argentina. Fondo, Reparaciones y Costas. Sentencia de 11 de mayo de 2007. Serie C N. ${ }^{\circ} 164$.

Corte Interamericana de Derechos Humanos. Caso Escué Zapata Vs. Colombia. Fondo, Reparaciones y Costas. Sentencia de 4 de julio de 2007. Serie C N. ${ }^{\circ} 165$.

Corte Interamericana de Derechos Humanos. Caso Zambrano Vélez y otros Vs. Ecuador. Fondo, Reparaciones y Costas. Sentencia de 4 de julio de 2007. Serie C N. 166.

Corte Interamericana de Derechos Humanos. Caso Cantoral Huamaní y García Santa Cruz Vs. Perú. Excepción Preliminar, Fondo, Reparaciones y Costas. Sentencia de 10 de julio de 2007. Serie C N. 167. 
Corte Interamericana de Derechos Humanos. Caso García Prieto y otros Vs. El Salvador. Excepciones Preliminares, Fondo, Reparaciones y Costas. Sentencia de 20 de noviembre de 2007. Serie C N. ${ }^{\circ} 168$.

Corte Interamericana de Derechos Humanos. Caso Albán Cornejo y otros. Vs. Ecuador. Fondo Reparaciones y Costas. Sentencia de 22 de noviembre de 2007. Serie C N. ${ }^{o} 171$.

Corte Interamericana de Derechos Humanos. Caso Salvador Chiriboga Vs. Ecuador. Excepción Preliminar y Fondo. Sentencia de 6 de mayo de 2008. Serie C N. ${ }^{\circ} 179$.

Corte Interamericana de Derechos Humanos. Caso Yvon Neptune Vs. Haití. Fondo, Reparaciones y Costas. Sentencia de 6 de mayo de 2008. Serie C N. ${ }^{\circ} 180$.

Corte Interamericana de Derechos Humanos. Caso Apitz Barbera y otros ( Corte Primera de lo Contencioso Administrativo») Vs. Venezuela. Excepción Preliminar, Fondo, Reparaciones y Costas. Sentencia de 5 de agosto de 2008. Serie C N. ${ }^{\circ} 182$.

Corte Interamericana de Derechos Humanos. Caso Castañeda Gutman Vs. México. Excepciones Preliminares, Fondo, Reparaciones y Costas. Sentencia de 6 de agosto de 2008. Serie C N. ${ }^{\circ} 184$.

Corte Interamericana de Derechos Humanos. Caso Heliodoro Portugal Vs. Panamá. Excepciones Preliminares, Fondo, Reparaciones y Costas. Sentencia de 12 de agosto de 2008. Serie C N. ${ }^{0} 186$.

Corte Interamericana de Derechos Humanos. Caso Bayarri Vs. Argentina. Excepción Preliminar, Fondo, Reparaciones y Costas. Sentencia de 30 de octubre de 2008. Serie C N. 187.

Corte Interamericana de Derechos Humanos. Caso Tiu Tojín Vs. Guatemala. Fondo, Reparaciones y Costas. Sentencia de 26 de noviembre de 2008. Serie C N. ${ }^{\circ} 190$.

Corte Interamericana de Derechos Humanos. Caso Ticona Estrada y otros Vs. Bolivia. Fondo, Reparaciones y Costas. Sentencia de 27 de noviembre de 2008. Serie C N. ${ }^{\circ} 191$.

Corte Interamericana de Derechos Humanos. Caso Valle Jaramillo y otros Vs. Colombia. Fondo, Reparaciones y Costas. Sentencia de 27 de noviembre de 2008. Serie C N. 192.

Corte Interamericana de Derechos Humanos. Caso Tristán Donoso Vs. Panamá. Excepción Preliminar, Fondo, Reparaciones y Costas. Sentencia de 27 de enero de 2009 Serie C N. 193.

Corte Interamericana de Derechos Humanos. Caso Perozo y otros Vs. Venezuela. Excepciones Preliminares, Fondo, Reparaciones y Costas. Sentencia de 28 de enero de 2009. Serie C N. ${ }^{\circ} 195$.

Corte Interamericana de Derechos Humanos. Caso Kawas Fernández Vs. Honduras. Fondo, Reparaciones y Costas. Sentencia de 3 de abril de 2009 Serie C N. ${ }^{\circ} 196$.

\subsubsection{Opiniones consultivas}

Corte Interamericana de Derechos Humanos. Asunto de Viviana Gallardo y otras, Decisión del 13 de noviembre de 1981, N. ${ }^{\circ}$ G 101/81. Serie A N. ${ }^{\circ} 10181$.

Corte Interamericana de Derechos Humanos. Opinión Consultiva OC-18/03 del 17 de septiembre de 2003. Serie A N. ${ }^{\circ}$ 18.

Corte Interamericana De Derechos Humanos. Garantías Judiciales en Estados de Emergencia (arts. 27.2, 25 y 8 Convención Americana sobre Derechos Humanos). Opinión Consultiva OC-9/87 del 6 de octubre de 1987. Serie A N. ${ }^{9} 9$.

Corte Interamericana de Derechos Humanos. Excepciones al Agotamiento de los Recursos Internos (arts. 46.1, 46.2.a y 46.2.b, Convención Americana sobre Derechos Humanos). Opinión Consultiva OC-11/90 del 10 de agosto de 1990 . Serie A N. ${ }^{o} 11$. 